U.S. DEPARTMENT OF THE INTERIOR

U.S. GEOLOGICAL SURVEY

\title{
STABILITY OF SUBMERGED SLOPES ON THE FLANKS OF THE HAWAIIAN ISLANDS, A SIMPLIFIED APPROACH
}

by

Homa J. Lee ${ }^{1}$, Michael E. Torresan ${ }^{1}$, and William McArthur ${ }^{1}$

Open-File Report 94-638

This report is preliminary and has not been reviewed for conformity with U.S. Geological Survey editorial standards. Any use of trade, product, or firm names is for descriptive purposes only and does not imply endorsement by the U.S.Government.

1U.S. Geological Survey, MS\#999, Menlo Park, CA 94025 


\section{DISCLAIMER}

Portions of this document may be illegible in electronic image products. Images are produced from the best available original document. 


\section{CONTENTS}

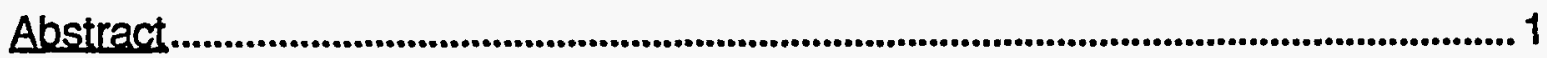

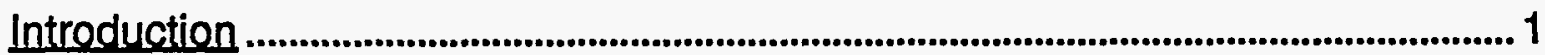

Approach

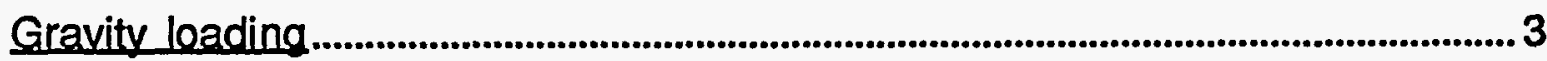

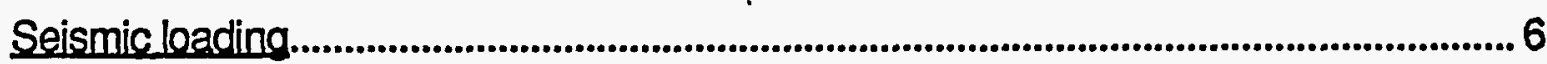

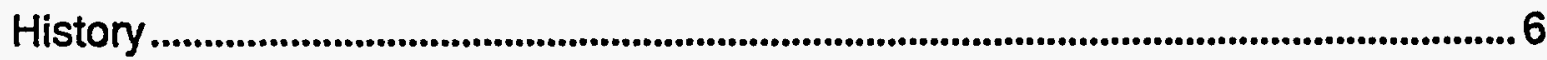

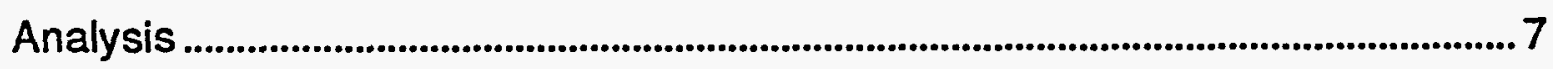

Isunami and storm wave loading .................................................................................. 8

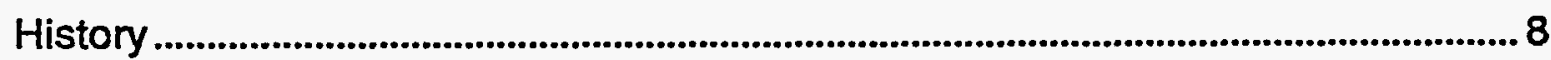

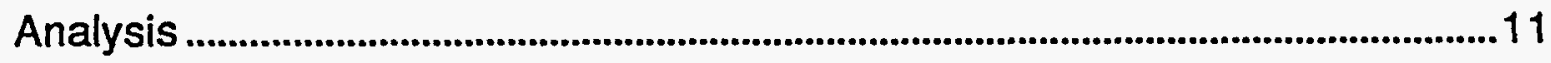

Sedimenttypes.......................................................................................................................... 12

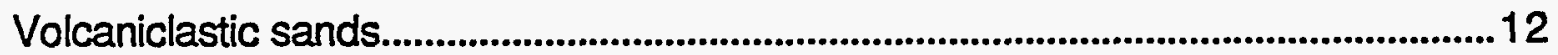

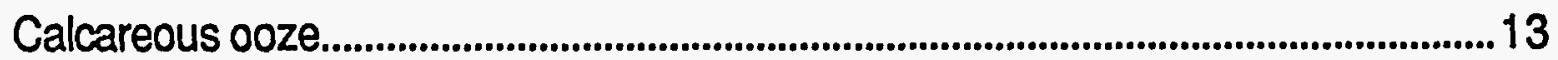

Fine-grained terrigenous sediment ................................................................................ 16

Synthesis and recommendations ........................................................................16

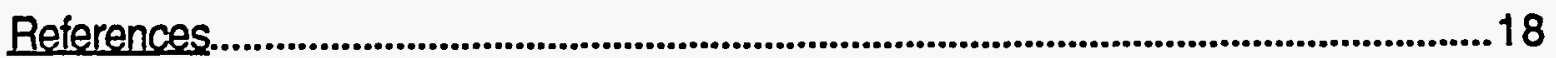

Table 1. Submarine cable damage descriptions associated with Hurricane

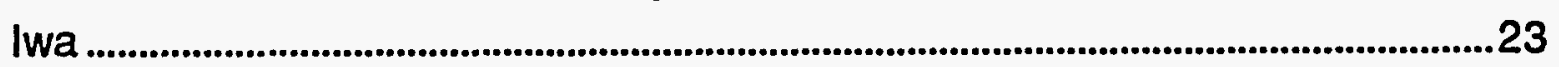

Table 2. OTEC study core station information (calcareous ooze) .........................24 
Table 3. Representative engineering properties of sediment from cores from the OTEC study area ....................................................................................................................25

Table 4. Fine-grained terrigenous sediment, site location....................................26

Table 5. Representative engineering properties of a fine-grained terrigenous sediment

Table 6. Maximum equilibrium slopes (angles of repose) for three general Hawailan sediment types.

Figure 1: Location and surficial sediment map around the Hawaiian Islands ..28

Figure 2: Bathymetric map around the principal Hawaiian Islands......................29

Figure 3: Storm track map for storms affecting the Hawaiian Islands ..................30

Figure 4: Location map showing location of OTEC study off Oahu, and a survey site off Kilauea ...................................................................................................................31

Figure 5a: Coring stations on the Kilauea margin .......................................................31

Figure 5b: Profile of water depths on the submarine flank of Kilauea Volcano 32

Figure 6: Location map for calcareous ooze stations 33

Appendix 1: Station Locations, box core descriptions, and selected physical properties of non-carbonate pelagic clay sediment from the Hawaiian EEZ .....34 Glossary of geotechnical terms........................................................................................52 
Abstract

Undersea transmission lines and shoreline AC-DC conversion stations and near-shore transmission lines are being considered as part of a system for transporting energy between the Hawailan Islands. These facilities will need to be designed so that they will not be damaged or destroyed by coastal or undersea landslides. Advanced site surveys and engineering design of these facilities will require detailed site specific analyses, including sediment sampling and laboratory testing of samples, in situ testing of sediment and rock, detailed charting of bathymetry, and two- or three-dimensional numerical analyses of the factors of safety of the slopes against failure from the various possible loading mechanisms. An intermediate approximate approach can be followed that involves gravity and piston cores, laboratory testing and the application of simplified models to determine a seismic angle of repose for actual sediment in the vicinity of the planned facility.

An even simpler and more approximate approach involves predictions of angles of repose using classification of the sediment along a proposed route as either a coarse volcaniclastic sand, a calcareous ooze, or a muddy terrigenous sediment. The steepest slope that such a sediment can maintain is the static angle of repose. Sediment may be found on slopes as steep as these, but it must be considered metastable and liable to fail in the event of any disturbance, storm or earthquake. The seismic angle of repose likely governs most slopes on the Hawaiian Ridge. This declivity corresponds to the response of the slope to a continuing seismic environment. As a long history of earthquakes affects the slopes, they gradually flatten to this level. Slopes that exceed or roughly equal this value can be considered at risk to fail during future earthquakes. There is most likely a wave loading angle of repose as well, but sufficient data to evaluate it with any degree of confidence are lacking. Seismic and static angles of repose for three sediment types are tabulated in this report.

Introduction

Submarine or coastal landslides or underwater turbidity currents could damage shoreline installations (AC-DC conversion stations and near-shore transmission lines) and undersea transmission cables. A shut-down of conversion facilities or damage to a submarine transmission line could cause 
widespread power failures, having a devastating effect on the economy of Hawaii if redundant sources of power are unavailable. Furthermore, geothermal wells would have to be shut down to avoid damage to Hawaiian Geothermal Project (HGP). These events would lead to unscheduled venting of production wells during the required shut-down period. Knowledge of natural marine hazards is required to support analysis in the Environmental Impact Statement (EIS) of potential impacts of HGP facilities. Thus, the purpose of this report is to identify any submarine hazards along the HGP cable route, and predict the probability of slope failures and other hazards that may affect cable integrity and operation.

\section{Approach}

In a general sense, slope failures are initiated when shear stresses oriented downslope (driving shear stresses) exceed the shear strength of the slope-forming and slope-mantling material; rock or sediment. In the marine environment, three types of downslope driving stresses may be present: gravity, seismically-induced stresses, and storm-wave-induced stresses. We will evaluate all three stresses by the simplified approach described below. The last two stresses (seismic and storm waves) are cyclically varying stresses that may cause a buildup in pore-water pressure that may reduce the shear strength. Evaluation of slope stability requires an estimate of the driving shear stress and a comparison with the appropriate shear strength of the slope forming material, taking into account strength degradation resulting from cyclic loading.

To evaluate submarine slope stability during the planning and design stages for submarine cables or engineered offshore structures, it will be necessary to perform detailed site specific analyses. These should include mapping with swath sonar, sediment sampling and laboratory testing of samples, in situ testing of sediment and rock, detailed charting of bathymetry, and two- or three- dimensional numerical analyses of the factors of safety of the slopes against failure from the various possible loading mechanisms. In this preliminary report, we cannot introduce most of the techniques that would be needed to perform such site-specific studies. Rather, we summarize some of the historical occurrences, and introduce concepts of regional analysis and simplified stability evaluation based upon end member types of sediment. 
Specifically, we consider the three types of loading listed above (gravity, earthquakes, and tsunami/storm waves) and three end-member sediment types: calcareous ooze, non-calcareous terrigenous sediment that may have interbedded basaltic turbidites (includes so-called pelagic clay), and coarse volcaniclastic sand. Our aim is to address these hazards and predict the probability of slope failures related to these stresses.

Figure 1 is a generalized sediment facies map (after Fan and Grunwald, 1971; and the Atlas of Hawaii, 1983) that shows the distribution of the endmember sediment types in the vicinity of the Hawaiian Islands (note that pelagic clay represents the distribution of the non-calcareous terrigenous end member). Figure 2 is a simplified bathymetric map from Oahu to Hawaii, compiled by the Branch of Pacific Marine Geology of the USGS. The bathymetric and facies maps can be used to locate the sediment types discussed below, and to determine the slope areas that may be more susceptible to stability problems during the three types of loading. Pápers by Fornari and Campbell (1983) and Mark and Moore (1983) include bathymetric and slope maps that are also applicable to this report. The slope maps by Mark and Moore (1983) show slope steepness (declivity) represented by color-coded intervals that are defined by the tangent of slope angle measured from the horizontal. The slope maps are useful to delimit the relative declivity of slopes along the proposed cable route. SeaBeam bathymetric maps by Chadwick and others (1993a, 1993b, and 1994) can be used to asses regional slopes on the south and west coasts of the island of Hawail. A report by Schwab and others (1986), was produced for the Ocean Thermal Energy Conversion project (OTEC) to evaluate available technology that could be applied for substrate and morphologic evaluation of steep slope environments offshore from tropical Islands. This study specifically considered stability factors that could affect a cold-water intake pipe for an OTEC plant, but the data can be applied to cableroute evaluation.

\section{Gravity loading}

The most simple type of slope stability analysis is one-dimensional and involves the concept of the semi-infinite slope. Such a slope is a plane surface, has a constant gradient everywhere, and extends for an infinite distance upslope, downslope, and along slope. Geometrically, such a slope is 
completely characterized by its declivity or gradient, $\alpha$. If only gravitational loads are exerted on the slope, the shear stress acting downslope, $\tau$, can be shown to equal:

$$
\tau=\gamma^{\prime} z \sin \alpha
$$

where $\gamma^{\prime}$ is the submerged density of the sediment (actual total density minus the density of sea water) and $z$ is the depth below the sediment-water interface (depth below the seafloor).

If the sediment is a purely frictional material (sands and some other types of non-plastic sediment), its strength behavior can be represented by a friction coefficient that is equal to $\tan \phi$ ( $\phi$ is defined as the friction angle, a property that can be measured in a laboratory test). The shear strength, $\tau_{f}$ (resistance to sliding along a particular plane) is represented by:

$$
\tau_{f}=\sigma_{n}{ }^{\prime} \tan \phi,
$$

where $\sigma_{n}{ }^{\prime}$ in the normal effective stress acting on the failure plane. Effective stresses are the total stresses acting minus the pressure in the pore water. A great deal of soil mechanics research has shown that sediment strength responds to effective stresses and not to the total stresses. (Lee and Edwards, 1986; Mitchell, 1976 and references therein). An important corollary to this rule is that sediment strength is unaffected by water depth. If there are no anomalous pore water pressures, the effective stress acting normal to the slope at some depth below the sediment-water interface, $z$, can be represented by:

$$
\sigma_{n}^{\prime}=\gamma^{\prime} z \cos \alpha
$$

Therefore,

$$
\tau_{f}=\gamma^{\prime} z \cos \alpha \tan \phi
$$


At the initiation of slope failure the gravitationally-induced shear stress will just equal the shear strength of the sediment $\left(\tau=\tau_{f}\right)$. Accordingly, setting the right sides of equations 1 and 4 equal to each other yields:

$$
\gamma^{\prime} z \sin \alpha=\gamma^{\prime} z \cos \alpha \tan \phi
$$

$$
\text { Simplifying, } \tan \alpha=\tan \phi \text { or } \alpha=\phi
$$

The result of this discussion is that, for a semi-infinite, purely frictional (cohesionless) slope, the peak slope declivity or gradient is the friction angle of the sediment. Such a declivity is termed the "angle of repose." If sand is slowly poured into a pile (such as in an hourglass), it will typically steepen to a particular angle, which will be roughly equal to the friction angle.

The concept of an "angle of repose" does not have to be reserved exclusively for gravitational loading. Indeed, as slopes are repeatedly exposed to storm wave or earthquake loading or both, they will also tend towards certain degrees of steepness that are related to the local storm wave or seismic environment. We can then speak of the storm wave or seismic angle of repose, which is lower than the static angle of repose represented by Eq. 6 .

A condition known as "liquefaction" sometimes occurs during earthquake loading of sands and other cohesionless materials on level or very-gentlysloping ground (Seed and Idriss, 1971). Liquefaction occurs when seismicallyinduced pore pressures within the sediment approach the lithostatic stress exerted by the weight of sediment particles. The strength of the sediment decreases dramatically and the sediment becomes capable of flowing almost like a liquid. Liquefied sand can erupt through fissures in level ground in volcano-like structures called sand boils. Structures founded on liquefied sediment can fail catastrophically. Liquefaction is the end-member of the seismic angle of repose discussion above. In a sense, liquefaction represents a seismic angle of repose approaching $0^{\circ}$.

In our simplified, regional evaluation of slope stability of sediment on the submerged flanks of the Hawaiian Islands, we will estimate the static, seismic, and storm wave angles of repose for three general sediment types (calcareous ooze, non-calcareous lower slope pelagic sediment with interbedded finegrained glassy turbidites, and coarse volcaniclastic sand). The next five 
sections consider the important characteristics of seismic loading and stormwave loading, including the nature and properties of each sediment type.

\section{Seismic loading}

History

Hawaiian seismicity is extremely well documented, and is associated with active volcanism, specifically dike injection (the forceful intrusion of magma into active rift zones) and landsliding, the failure or movement of portions of or whole-flanks of a volcano (Swanson and others 1976; Lipman and others 1985; Moore and others 1989; Wyss and Koyanagi 1992; Normark and Herring, 1993, . and Klein, 1994). Wyss and Koyanagi (1992) and Klein (1994) show that the seismic hazard in parts of Hawaii is comparable to that along the San Andreas Fault in California or the Gulf of Alaska.

Large earthquakes can reach magnitude $8(M=8)$ and intensity XII (l=XII), with radii of the felt areas reaching up to $600 \mathrm{~km}$, the extent of the principal Hawaiian Islands. Thus, any cable route will be susceptible to earthquakes and associated hazards that include ground shaking, liquefaction, subareal or submarine landslides, sediment gravity flows (turbidity currents and debris flows), and tsunamis.

Klein (1994), using historical earthquake data from 1823 to 1992, suggests average recurrence intervals for $M>5.5$ earthquakes of 3.4-5.0 years, for $M>7$ events of 29-44 years, and for $M>8$ events of 120-190 years. Expected frequencies of events having intensities of $V$ or greater is about 4 per year (Wyss and Koyanagi, 1992).

Macroseismic data compiled by Wyss and Koyanagi (1992) for 56 moderate to large historical earthquakes, occurring between 1823 and 1989 and ranging in magnitude from 4.7 to 7.9 , were used to construct isoseismal maps that suggest unusually strong attenuation of seismic waves in the crust in the Hawaiian area, more so than observed elsewhere in the United States. Measured and calculated ground accelerations (Klein , 1994), show that peak ground acceleration (PGA) in parts of Hawaii is greater than or comparable to similar relationships for the western U.S. The active south flanks of Mauna Loa and Kilauea are most prone to seismic hazards. Klein (1994) calculates that these active flanks can expect PGA of up to $1.0 \mathrm{~g}$ within 50 years $(90 \%$ 
probability), comparable to expected PGA's along the San Andreas fault of California, and the Gulf of Alaska. Historic earthquake intensity maps in Wyss and Koyanagi (1992) show that for earthquakes on the south flanks of Mauna Loa and Kilauea with $M \geq 6$, earthquake intensities of $V$ or $V I$ can be felt as far away as Oahu.

Analysis

Earthquakes generate horizontal and vertical accelerations that induce shear and normal stresses in the sediment column. The shear stresses have the potential for driving the sediment to failure and respond most strongly to horizontal accelerations. The response of the earth to the propagation of seismic waves is very complicated and not easily represented by a small number of parameters. However, a simplified approach that has been used with some success (Lee and Edwards, 1986) is to assume that a given earthquake can be represented by a characteristic horizontal acceleration, $k$ (expressed in g's, or multiples of the gravitational acceleration). In addition, the assumption is made that the horizontal acceleration is applied over such a long period of time that the stresses induced by it are considered constant. This approach (Lee and Edwards, 1986; Morgenstern, 1967) is termed the "pseudostatic" approach and leads to seismically-induced downslope shear stresses, $\tau_{s}$, equal to:

$$
\tau_{s} / \gamma^{\prime} z=\sin \alpha+\left(k \gamma / \gamma^{\prime}\right)
$$

where $\gamma$ is the total sediment density $\left(\gamma^{\prime}+\right.$ density of sea water).

These downslope shear stresses can be balanced against an appropriate shear strength to determine the relative stability of a given slope. Because earthquakes occur over a short time span and because the loading is cyclic, pore water pressures generated by shear may be appreciable and cannot fully dissipate. As a result, the description of the shear strength of sediment during seismic loading is not as simple as that given above for simple gravitational loading of a cohesionless sediment. Lee and Edwards (1986) suggested an 
equation for cyclic, undrained (retarded pore pressure dissipation) shear strength, $s_{u r}$, that can be simplified to the following:

$$
s_{u r} / \gamma^{\prime} z=A_{c} A_{r} S(O C R)^{m}
$$

in which $A_{c}$ and $A_{r}$ are strength correction factors. The factor $A_{c}$ accounts for sample preparation conditions applied in the laboratory and is typically found to equal about 0.8 . The factor $A_{r}$ is the cyclic-strength degradation factor and relates io the proportion of the shear strength that remains after earthquake shaking and resulting pore-water pressure increase. The factor $A_{r}$ can be measured using cyclic strength testing in the laboratory and ranges from 0.5 or lower for silts to over 1.0 for clays. The ratio, $S$, of "undrained shear strength to consolidation stress for normal consolidation" is measured in the laboratory and ranges from values of 1.0 or higher for sands and coarse silts to values of 0.3 or lower for clayey silts and clays. The quantity OCR is the overconsolidation ratio (maximum past effective stress to present overburden-effective stress) and $m$ is a sediment property typically equal to about 0.8 . The quantity " $(O C R)^{m \text { " is }}$ set equal to 1 for thick units of normally consolidated sediment, i.e., those that have not been preloaded by previously existing overburden or tectonic stress.

Lee and Edwards (1986) investigated a series of submarine slope failures that were likely initiated by earthquakes along the seismically active margins of California and southern Alaska. Knowing that the sediment had failed, using the stress formulation given by Eq. 7, using the strength formulation of Eq. 8 , and using sediment properties measured in the laboratory, they found that $a$ pseudo-static acceleration, $k$, of 0.13 to $0.14 \mathrm{~g}$, corresponded to the initiation of failure under the environmental conditions present on these margins. Note that the factor, $k$, used by Lee and Edwards (1986) is empirical and is not equal to $P G A$, measured during or estimated for a particular earthquake. However, because approximately the same PGA is expected for the south flanks of Kilauea and Mauna Loa as for California and southern Alaska (Klein, 1994), values of $\mathrm{k}=0.13$ to $0.14 \mathrm{~g}$ can be used for submarine slope stability analysis in these Hawaiian locations. For less seismically active parts of Hawaii, somewhat lower values could be used. The appropriate value of " $k$ " should most likely be decreased in proportion to anticipated decreases in PGA, such as are given by by Klein (1994). 
Tsunami and Storm-Wave Loading

History

Hawaii's location near the center of the Pacific Basin and its high seismic activity make any cable routed from HGP to other islands susceptible to slope instability resulting from tsunamis and storm waves. Cox and Morgan (1977), Tsunami Reports (1978-present), the Atlas of Hawaii (1983), and Fletcher and others (in prep), are the major sources of wave information from the Hawaiian Islands. Fletcher and others (in prep), document and review historical tsunami, storm wave, and high wind occurrences for the islands of Kauai, Oahu, Molokai Lanai, Maui, and Hawaii. They present detailed maps and tables documenting historic storm tracks and tsunami and storm wave occurrences. They list associated parameters that include wave height, wave runup, and damage estimates; assigning specific hazard intensities and hazard ratings on 1:50,000 scale maps for the complete coastline of each major Hawaiian Island. This document should be obtained (contact Dr. Charles Fletcher, University of Hawaii, School of Ocean and Earth Science and Technology 2525 Correa Road, Honolulu, Hawaii 96822; tel: 808-956-2582; email:

fletcher@kiawe.soest.hawaii.edu) for assessing the hazards addressed in our report.

Owing to the high volcanic and seismic activity around the Pacific Basin, and because Hawaii is one of the most geologically active regions on earth, tsunamis are a serious hazard to the Hawaiian Islands. Dudley and Lee (1988) show that from 1813 to 1988 (175 yrs) Hawaii has experienced 95 tsunamis, with the last large seismic wave striking the Islands in 1960. Maximum recorded tsunami heights exceeded $15 \mathrm{~m}$ on the north and northeast shores of several islands (Kauai, Oahu, Molokai, Maui, and Hawaii), and exceeded $6 \mathrm{~m}$ on the south and southwest shores of the same islands (Cox and Morgan, 1977; Cox, 1980; Atlas of Hawaii, 1983; Fletcher and others in prep). Numerical modeling of the November 29, 1975, tsunami is presented in studies by Mader (1984; 1988-chapter 4 pages 105-117), Loomis (1975 and 1978), and Sklarz and others (1979).

Storm waves also pose a serious hazard to the Hawaiian coastal zone (Shaw, 1981; U.S. Army Corps Engineers Pacific Ocean Division, 1983; Normark and Herring, 1993; Schroeder, 1993; and Fletcher and others, in prep). 
The historical data base of tropical storms and hurricanes (cyclones) that affect the Hawaiian Islands and the central Pacific is summarized in a report by Shaw (1981) and a hazards atlas by Fletcher and others (in prep). Our knowledge of, and data base for, central Pacific storms is a direct function of technology. Shaw (1981) listed nineteen hurricanes that occurred in the central Pacific between 1832 and 1949 and seventeen that occurred between 1950 and 1959. With the advent of satellite data, thirty-four hurricanes were identified between 1960 and 1969. The period between 1970 and 1979 saw another thirty-four Pacific hurricanes, with the number growing to fifty-four during the 1980's. Accordingly, the last two decades have seen 105 tropical storms in the central Pacific, an average of 4.5 storms per year. Major storm tracks that have affected the Hawaiian Islands since 1950 are presented in Figure 3, (Modified from Schroeder, 1993; the Atlas of Hawaii 1983; and Fletcher and others, in prep). Two major hurricanes, Iwa in November of 1982 and Iniki in September of 1992, struck the Hawaiian Islands within a decade. Both storms severely affected Oahu and devastated Kauai. Storm waves generated by Hurricane Iwa are believed to have initiated sediment gravity flows that disrupted submarine communication cables off Kahe Point, Oahu (Noda, 1983, Dengler and others, 1984a and 1984b; Cox, 1986; Tsutsui and others, 1987; Normark and Herring, 1993; Normark and others, 1993).

Storms generate large swells and high winds that have varying degrees of impact on the Hawaiian Islands, and storm-generated waves can exceed $10 \mathrm{~m}$ (Atlas of Hawaii, 1983; U.S. Army Corps of Engineers, 1983; Fletcher and others, in prep, tables 4 and 5). Cox (1986) and Mader (1988) state that the one-dimensional numerical models used to estimate hurricane storm surges on continental coasts failed to describe the Iwa storm surge; significant storm surges were not expected to occur on islands with steep coasts such as those of the Hawaiian Islands. The nature of the important effects neglected in the usual model needs to be determined. Obviously, not all of the documented central Pacific storms affect the Hawaiian Islands, and actual hurricane strikes are rare (Fletcher and others, in prep). But, many times it is the "near-misses" that lead to the most severe impacts on the exposed islands, as was the case with Hurricane Iwa and the island of Oahu. 
Analysis

As the crests and troughs of large seismic or storm waves pass over submerged slopes, they generate relatively high water pressure zones adjacent to low water pressure zones. These alternating pressured zones generate zones of relatively high shear stress halfway between the crests and troughs. Because the waves are propagating through, the induced shear stress $\left(\tau_{w}\right)$ at any point in the sediment will vary cyclically and may alternate its direction. Seed and Rahman (1978) presented a version of the following equation to estimate the induced shear stress as a function of wave characteristics and depth in the sediment column:

$$
\tau_{w} / \gamma^{\prime} z=\sin \alpha+\pi \gamma_{w} H /\left[\gamma^{\prime} L \cosh (2 \pi d / L)\right]
$$

where $\gamma_{w}$ is the density of sea water, $H$ is the wave height, $L$ is the wave length, and $d$ is the water depth.

Because the cyclic loading exerted by storm waves has many similarities to that caused by an earthquake, a strength formulation similar to that given by Eq. 8 can typically be applied. The appropriate value of Ar used for storm waves will differ from that used for earthquakes because a storm would typically have a greater duration and include many more cycles of loading.

Wave-induced slope failure may have occurred during Hurricane Iwa in 1982 (Noda, 1983; Dengler and others, 1984a and 1984b; Tsutsui and others, 1987; and Normark and others, 1993). In an area off the southwest coast of Oahu, arrays of current meters were displaced downslope and telecommunication cables were disrupted (Table 1). Displacement of the current meters to deeper water was associated with water current speeds as much as $2.2 \mathrm{~m} / \mathrm{s}$. The flat housings and flat surfaces of the current meters had accumulated significant amounts of sediment.

Normark and others (1993) believe that sediment slope failure occurred near the shelf break in about $100 \mathrm{~m}$ water depth as a result of cyclic loading by waves resulting from Hurricane Iwa. Direct measurements of the wind and wave conditions for the Kahe Point area do not exist, but storm conditions were reconstructed by Noda (1983) and show a significant wave height of about $5 \mathrm{~m}$, maximum heights of about $9 \mathrm{~m}$ and $30-35$ knot sustained winds (Tsutsui and others 1987). An alternate, but less likely, scenario might involve sediment 
resuspension by downslope currents and storm surges. After a critical mass of sediment was resuspended, a downslope gravity-driven turbidity current could result.

\section{Sediment Types}

Volcaniclastic Sands

When active lava ilows enter the sea, as they have nearly continuously since 1986 as a result of the Kupaianaha eruption of Kilauea volcano, they produce large quantities or highly angular, coarse volcaniclastic sand. At points of lava entry, sand and lava flow accumulations form low benches or lava deltas. Parts of these benches periodically break free of the rest of the lava delta without warning and slide into the ocean (Hon and others, 1993). Occasionally, lava delta failures are associated with moderate earthquakes.

Immediately offshore of the lava deltas is a very steep slope of $25^{\circ}$ to $40^{\circ}$ on the southern submarine flank of Kilauea (Tribble, 1991; Chadwick and others, 1993; Smith, 1993). The slope is apparently at the gravitational angle of repose of the sand as any disturbance by a diver triggers a small landslide (Tribble, 1991). The slope flattens somewhat farther offshore, where it has a gradient of $25^{\circ}-30^{\circ}$, between water depths of 50 and $250 \mathrm{~m}$. At greater depths $(1000-2500 \mathrm{~m})$, the gradient is relatively constant at $10^{\circ}-15^{\circ}$.

The U.S.G.S. conducted a sampling cruise to the southern submerged margin of Kilauea in 1991 and sampled volcaniclastic deposits in water depths ranging from $1000 \mathrm{~m}$ to $2800 \mathrm{~m}$. The location of the study area is shown in Figs. 4 and $5 \mathrm{a}$; locations of coring stations and the slope gradients at each station are shown in Fig. 5b. In virtually all locations, the sediment sampled was coarse, angular volcanic glass shards ranging in size from medium- to coarse-sand. Bottom photography showed a rippled sand surface suggesting episodic downslope flow of water. An examination of recently available Sea Beam bathymetry for the southeast slope of the island of Hawaii (Chadwick and others 1993a, and 1994) shows an anomalously smooth slope extending all the way from Cape Kumukahi to Papau Seamount, a distance of about $50 \mathrm{~km}$. The smooth slope extends from the coastline down to a water depth of 2500 to 3000 $\mathrm{m}$, where the slope is interrupted by a wide $(10 \mathrm{~km})$ terrace, which is likely the surface of a large back-rotated slump block. Below the terrace, and elsewhere, 
the slope is highly irregular and rough, indicative of a rocky rather than sandy bottom.

We suggest that the smooth slope apparent on the bathymetric map by Chadwick and others (1993a), is covered completely by volcaniclastic sand and that this sand is ubiquitous to the upper part of the SE submerged slope of Kilauea (Hon and others 1993; Smith 1993; Fig 1). Furthermore, we suggest that the slope steepness is a fairly accurate measure of both the gravitational and seismic angle of repose of the sediment. The upper slope off the present lava deltas would represent the gravitational angle or repose, which would range between $25^{\circ}$ and $40^{\circ}$. These values would be equivalent to the friction angle, $\phi$, and are typical of coarse, loose sand. Sands farther down the slope might well have moved to their present locations under the influence of seismic loading. The slopes in these locations $\left(10^{\circ}-15^{\circ}\right)$ are likely a good measure of the seismic angles of response for this sand in the seismic environment of the Kilauea margin. Examples of the seismicity of this area include a magnitude 7.2 earthquake that occurred near Kalapana in 1975, and an approximated 7.9 magnitude earthquake that occurred there in 1868 (Clague and Denlinger, 1993). Excellent reviews of historical earthquakes, their magnitudes, intensities, peak accelerations, and the probabilities of high accelerations and high magnitude earthquakes occurring in the future are presented in Wyss and Koyanagi (1992) and Klein (1994).

Similarly, the upper portions of the Alika Slide, a debris avalanche located on the southwest flank of Mauna Loa volcano, is characterized by a smooth, steep slope to a depth of $3500 \mathrm{~m}$ (Figure 2; Moore and others, 1989; Chadwick and others, 1993 and 1994; ). Sampling operations conducted during the 1991 cruise showed that the upper part of Alika Slide is mantled with coarse volcaniclastic material, similar to that sampled from the submarine slope of Kilauea (Fig 1 and Appendix 1- box core description B30), to a depth of $2550 \mathrm{~m}$. Stability and sediment behavior on this portion of Mauna Loa is likely similar to that described above for the submerged flank of Kilauea.

\section{Calcareous Ooze}

Calcareous ooze (or foraminiferal ooze) is composed predominantly of the remains of organisms that build their hard parts out of calcium carbonate. This type of sediment forms when the input of non-calcareous material is relatively 
low and the water depth is shallower than the calcite-compensation depth (CCD). In the vicinity of the Hawaiian Islands, the CCD occurs at about $4 \mathrm{~km}$ (Berger and Winterer, 1974). Accordingly, calcareous ooze is found where there is little modern volcanic activity, terrigenous input from rivers is low, and the water depth is shallower than $4 \mathrm{~km}$. In the Hawaiian Islands, some calcareous ooze can be expected on the submarine slopes of Kohala volcano and older volcanoes to the northwest. Figure 1, a facies map, shows a wellstudied calcareous deposit situated on the insular slope southwest of Oahu, where preliminary engineering investigations were conducted for siting an Ocean Thermal Energy Conversion (OTEC) facility (Yuen, 1981).

As part of the study for the proposed OTEC facility, four gravity core samples were taken in January, 1981 and subjected to detailed geotechnical studies, including static and cyclic triaxial, consolidation, and index property testing (Winters and Lee, 1982). The location of the study area is shown in Fig. 4 , locations of the cores are shown on Fig. 6, and coordinates, water depths, and bottom slopes are listed in Table 2. These core stations happened to have been located in the vicinity of storm-wave generated failures that occurred in 1982 and were reported upon by Noda (1983), Dengler and others (1984a and 1984b), Tsutsui and others (1987) and Normark and others (1993).

For static gravitational loading, the sediment should be stable up to a slope of the static friction angle, $\phi$. From Table 3, the average value of $\phi=38^{\circ}$; accordingly, the static angle of repose of the sediment is $38^{\circ}$. Normark and others (1993) report a steep slope of $30^{\circ}$ to $40^{\circ}$ directly below the shelf break, extending to a water depth of $350 \mathrm{~m}$. Limited accumulations of calcareous ooze could develop on such a slope but any disruption, whether by storms or earthquakes would likely cause a failure of the sediment. That is probably what happened when Hurricane Iwa struck in November 1982. The calcareous ooze, coral fragments and other sediment found on the steep slope failed and moved a considerable distance downslope, displacing current meter arrays and submarine cables.

Below the steep slope just past the shelf break, the declivity gradually decreases from $30^{\circ}-40^{\circ}$ to $5^{\circ}-10^{\circ}$, as water depth increases from $350 \mathrm{~m}$ to 600 $\mathrm{m}$. Between $600 \mathrm{~m}$ and $1500 \mathrm{~m}$ the slope is relatively constant with a mean of $7^{\circ}$. It is from this section that the four geotechnical cores were taken. The results of the geotechnical tests (Table 3 ) provide all the sediment properties needed to evaluate the sediment strength during seismic loading (Eq. 8) for this 
section. Core station information (Table 2) and sediment properties (Table 3) provide needed input to Eq. 7, which evaluates the pseudo-static shear stress exerted by an earthquake. For the limiting condition of cyclic shear strength equal to seismically induced shear stress, Eqs. 7 and 8 can be combined to yield a predictor equation for $k$, the pseudo-static earthquake acceleration needed to cause slope failure:

$$
\begin{aligned}
& A_{c} A_{r} S(O C R)^{m}=\sin \alpha+\left(k \gamma / \gamma^{\prime}\right) \\
& k=\left[A_{c} A_{r} S(O C R)^{m}-\sin \alpha\right] \gamma^{\prime} / \gamma \\
& k=[(0.68)(0.76)(0.5)-\sin (7.2)](5.1 / 15.1) \\
& =0.045 \mathrm{~g}, \text { ignoring overconsolidation effects }(O C R=1)
\end{aligned}
$$

This value of $\mathrm{k}(0.045 \mathrm{~g})$ is about $1 / 3$ that reported by Lee and Edwards (1986) for limiting stability off the coasts of California and Alaska. That is, according to the approach of Lee and Edwards (1986), the calcareous oozecovered slope off Oahu would not be stable if it were off California or southern Alaska. That the sediment has accumulated on the Oahu slope is probably an indication of a reduced level of seismicity for the island of Oahu. However, given that the area does have some seismicity and that $k=0.045 \mathrm{~g}$ is a fairly low value, it seems reasonable (and conservative) to assume that such a value is representative of limiting stability of the area near Oahu.

The critical slope angle for seismic stability (seismic angle of repose) can be obtained by solving Eq. 11 for $\sin \alpha$ :

$$
\sin \alpha=\left(k \gamma / \gamma^{\prime}\right)-A_{c} A_{r} S(O C R)^{m}
$$

The value of $k=0.045 \mathrm{~g}$ (and values of geotechnical properties estimated for the sediment) could be inserted in Eq. 12 to yield an estimate of the seismic angle of repose. A similar approach is to assume that the mid-Oahu slope (600-1500 m, declivity of about $\left.7^{\circ}\right)$ is presently near the seismic angle of repose. The relative stability of other carbonate-covered slopes can be evaluated by comparing their declivities with $7^{\circ}$. Slopes that are much steeper could become unstable in major earthquakes affecting the area.

In principle, storm-wave induced stability of carbonate-covered slopes in water depths of $0-200 \mathrm{~m}$ could be evaluated by using the properties given in 
Table 3, design storm wave characteristics, and Eq. 9. However, even though a storm-wave-induced failure likely occurred in 1982, we cannot test the method with these data. The slope directly below the shelf break is so steep (near the static angle of repose), that any significant disturbance could have initiated failure. Therefore no limits can be placed on the critical wave height for comparison with the actual wave heights that occurred.

Fine-grained terrigenous Sediment

We sampled a fine-grained terrigenous sediment southeast of the island of Hawaii (location given in Table 4) in 1991 and have conducted a limited geotechnical testing program on one of the cores. This muddy sediment likely represents a fine-grained end member for the slopes and basins surrounding Hawaii and is called pelagic clay by many (Fig. 1). Table 5 shows sediment properties that have been obtained to date. The sediment friction angle, $\phi$, is $37^{\circ}$, indicating that it could maintain static stability up to this declivity. Most likely, however, the processes that would produce such a muddy sediment would not leave a deposit on such a steep slope. A more likely situation would require evaluating the stability of this fine-grained sediment on a gentler slope during an earthquake. In this case, Eq. 12 could be used with the properties from Table 5 and a $\mathrm{k}$ of $0.045 \mathrm{~g}$ (representative of Oahu, see calcareous ooze section above) to 0.13 (representative of the south flanks of Kilauea and Mauna Loa) to calculate the seismic angle of repose (Table 6).

Appendix 1 shows typical non-calcareous terrigenous sediment and some associated physical properties. This sediment, which can mantle some of the island flanks and fills the basins (Fig. 1 ) is typically composed $50 \%$ or more clay, is soft (as shown from shear strength values determined by vane shear) and varies in sensitivity from medium sensitive to slightly quick. Thin turbidite layers composed of silty to sandy basaltic glass are interbedded in many of the cores collected adjacent to the island of Hawaii.

\section{Synthesis and Recommendations}

As discussed previously, advanced site surveys and engineering design will require detailed site specific analyses. These will include sediment sampling and laboratory testing of samples, in situ testing of sediment and rock, 
detailed charting of bathymetry, and two- or three-dimensional numerical analyses of the factors of safety of the slopes against failure from the various possible loading mechanisms. An intermediate approximate approach could be followed that would involve gravity and piston cores, laboratory testing and the application of Eq. 12 to determine a seismic angle of repose for actual sediment in the vicinity of the planned facility. Such an approach would be similar to that recommended by Lee and Edwards (1986).

An even simpler and more approximate approach would involve using previously predicted angles of repose as discussed in this report and summarized in Table 6. To use such an approach, one must classify the sediment along a proposed route as either a coarse volcaniclastic sand, a calcareous ooze, or a muddy terrigenous sediment similar to that sampled at Station 15 (Table 4). Next, Table 6 shows the steepest slope that such a sediment can maintain, the static angle of repose. Sediment may be found on slopes as steep as these, but it must be considered metastable and liable to fail in the event of any disturbance, storm or earthquake.

The seismic angle of repose likely governs most slopes on the Hawaiian Ridge. This declivity corresponds to the response of the slope to a continuing seismic environment. As a long history of earthquakes affects the slopes (Wyss and Koyanagi, 1992; and Klein, 1994), they gradually flatten to this level.

Slopes that exceed or roughly equal this value can be considered at risk to fail during future earthquakes. There is most likely a wave loading angle of repose as well, but we lack sufficient data to evaluate it with any degree of confidence. 


\section{References}

Atlas of Hawaii, Second Edition, 1983. University of Hawaii, Department of Geography, R. Warwick Armstrong editor, University of Hawaii Press, Honolulu, Hawaii, 238 p.

Berger, W.H. and Winterer, E.L., 1974. Plate stratigraphy and the fluctuating carbonate line, Spec. Publications Int. Ass. Sediment., vol. 1, p. 11-48.

Chadwick, W.W., Jr., Smith, J.R., Jr., Moore, J.G., Clague, D.A., Garcia, M.O., and Fox, C.G., 1993a. Bathymetry of south flank of Kilauea Volcano, Hawaii, U.S. Geological Survey, Miscellaneous Field Studies, Map MF2231.

Chadwick, W.W., Jr., Moore, J.G., Garcia, M.O., and Fox, C.G., 1993b.

Bathymetry of southern Mauna Loa Volcano, Hawaii, U.S. Geological Survey, Miscellaneous Field Studies, Map MF-2233.

Chadwick, W.W., Jr., Moore, J.G., and Fox, C.G., 1994. Bathymetry of southwest flank of Mauna Loa Volcano, Hawaii, U.S. Geological Survey, Miscellaneous Field Studies, Map MF-2255.

Clague, D.A., and Denlinger, R.P., 1993. The M7.9 1868 earthquake: Hawaii's active landslides, EOS v. 74, no. 43, p.635.

Cox, D.C., and Morgan, J., 1977. Local tsunamis and possible local tsunamis in Hawaii, Report HIG-77-14, Hawaii Institute of Geophysics, Honolulu, Hawaii, November 1977, 118 p.

Cox, D.C., 1980. Source of the tsunami associated with the Kalapana (Hawaii) earthquake of November 1975: Hawaii Institute of Geophysics Report HIG80-8.

Cox, D.C., 1986. The Iwa storm surge in Hawaii, November 1982: University of Hawaii Environmental Center Report. 
Dengler, A.T., Noda, E.K. Wilde, Pat, and Normark, W.R., 1984a. Slumping and related turbidity currents along proposed OTEC cold-water-pipe route resulting from Hurricane Iwa, proceedings of the 1984 Offshore Technology Conference, Houston, TX, OTC 4702, p. 475-480.

Dengler, A.T., Wilde, P., Noda, E.K., and Normark, W.R., 1984b. Turbidity currents generated by Hurricane Iwa, Geo-Marine Letters, V4, p. 5-11.

Dudley, W.C., and Lee, M., 1988, Tsunamil. University of Hawaii Press, Honolulu, $132 \mathrm{pp}$.

Fan, P.F., and Grunwald, R.R., 1971. Sediment distribution in the Hawaiian archipelago, Pacific Science, V 25, pp. 484-488.

Fletcher, C.H., Stewart, I., Eckelman, J.J., Bays, B., Hwang, D.J., and Ress, A., in prep. Atlas of natural hazards in the Hawaiian coastal zone, University of Hawaii, School of Ocean and Earth Science and Technology, State of Hawaii, Governor's Office of State Planning, Coastal Zone Management Program.

Fornari, D.J., and Campbell, J.F., 1983. Submarine topography around the Hawaiian Islands. U.S. Geological Survey Professional Paper 1350, Chapter 4, pp. 109-124.

Garcia, M.O., and Hull, D.M., 1994. Turbidites from giant Hawaiian landslides : results from Ocean Drilling Program site 842, Geology, V22, pp. 159-162.

Hon, K., Mattox, T., Kauahikauna, J., and Kjargaard, 1993. The construction of pahoehoe lava deltas on Kilauea Volcano, Hawaii, EOS, Transactions, vol 74, no 43, p. 616.

Klein, F., 1994. Seismic hazards at Kilauea and Mauna Loa Volcanoes, Hawaii: U.S. Geological Survey Open-File Report 94-216.

Lee, H.J., and Edwards, B.D., 1986. Regional method to assess offshore slope stability, Journal of Geotechnical Engineering, ASCE, v. 112, p. 489-509. 
Lipman, P.W., Normark, W.R., Moore, J.G., Wilson, J.B., and Gutmacher, C.E., 1988. The giant submarine Alika debris slide, Mauna Loa, Hawaii, Journal of Geophysical Research, v. 93, no. BH5, p. 4279-4299.

Loomis, H.G., 1975. The tsunami of November 29, 1975, in Hawaii: Hawaii Institute of Geophysics Report HIG-75-21.

Loomis,, H.G., 1978. On defining the source of the 1975 tsunami in Hawaii: JIMAR Report to the Nuclear Regulatory Commission.

Mader, C.L., 1984. A landslide model for the 1975 Hawaii tsunami: Science of Tsunami Hazards, vol. 2, no. 2, pp. 71-77

Mader, C.L., 1988. Numerical modeling of water waves: (Chapter 4) University of California Press.

Mark, R.K., and Moore, J.G., 1983. Slopes on the Hawaiian Ridge, U.S. Geological Survey Professional Paper 1350, Chapter 3, pp. 101-107.

Mitchell, J.K., 1976. Fundamentals of soil behavior: John Wiley and Sons, New York, N.Y., 442 p.

Moore, J.G., Clague, D.A., Holcomb, R.T., Lipman, P.W., Normark, W.R., and Torresan, M.E., 1989. Prodigious submarine landslides on the Hawaiian Ridge: Journal of Geophysical Research, v. 94, no. B12, p. 17,465-17,484.

Morgenstern, 1967. Submarine slumping and the initiation of turbidity currents, in A.F. Richards, Ed., Marine Geotechnique, University of Illinois Press, Urbana, p. 189-210.

Noda, E.K., 1983. Effects of Hurricane Iwa, November 23, 1982 offshore of Kahe Point, Oahu, Technical Report for Res. Corp., University of Hawaii, Honolulu, Hawaii, 56 p. 
Normark, W.R., and Herring, H.H., 1993. Annotated bibliography: marine geologic hazards of the Hawaiian Islands with special focus on submarine slides and turbidity currents, U.S. Geological Survey Open-File Report 93$551 \mathrm{C}, 29 \mathrm{p}$.

Normark, W.R., Wilde, Pat, Campbell, J.F., Chase, T.E., and Tsutsui, Bruce, 1993. Submarine slope failures initiated by Hurricane Iwa, Kahe Point, Oahu, Hawaii, in Submarine Landslides: Selected Studies from the U.S. Exclusive Economic Zone, U.S.G.S. Bulletin 2002, p. 197-204.

Schroeder, J., 1993 - Hurricane history, unpublished University of Hawaii Report.

Schwab, W.C., Chase, T.E., Normark, W.R., Wilde, P., and Seekins, B.A., 1986. Generic assessment of steep-slope seabed environments: identification of sediment cover and evaluation of swath sonar systems of OTEC site mapping, U.S. Geological Survey Open-File Report 86-333-A, 101 p.

Seed, H.B. and Idriss, 1971. Simplified procedure for evaluating soil liquefaction potential, Journal of the Soil Mechanics and Foundation Engineering Division, American Society of Civil Engineers, v. 97, no. SM9, p. $1249-1273$.

Sklarz, M.A., Spielvogel, L.Q., and Loomis, H.G., 1979. Numerical simulation of the November 29, 1975, Island of Hawaii tsunami by the finite element method: Journal of Physical Oceanography, vol. 9, no. 5, pp. 1022-1031.

Seed, H.B. and Rahman, M.S., 1978. Wave-induced pore pressure in relation to ocean floor stability of cohesionless soils, Marine Geotechnology, v. 3, p. 123-150.

Shaw, S., 1981. Comprehensive survey of documented tropical cyclones over the period 1832-1979, Central Pacific Hurricane Center. 
Smith, J.R., 1993. Extent and depositional processes of hyaloclastite and lava delta debris offshore Kilauea Volcano, Hawaii, EOS Transactions, v. 74, no. 43, p. 617 .

Swanson, D.A., Duffield, W.A., and Fiske, R.S., 1976. Displacement of the south flank of Kilauea- the result of forceful intrusion of magma into the rift zones: U.S., Geological Survey Professional Paper 963, p. 1-39.

Tribble, Gordon, 1991. Underwater observations of active lava flows from Kilauea volcano, Hawaii, Geology, v. 19, p. 633-636.

Tsunami Reports, 1978-. Honolulu: International Tsunami Information Center.

Tsutsui, B.O., Campbell, J.F., and Coulbourn, W.T., 1987. Storm-generated, episodic sediment movements off Kahe point, Oahu, Hawaii, Marine Geology, v. 76, p. 281-299.

U.S. Army Corps of Engineers, Pacific Ocean Division, 1983. Post disaster report; Hurricane Iwa, 23 November 1982, 171 p.

Winters, W.J. and Lee, H.J., 1982. Evaluation of geotechnical properties and slope stability of a calcareous ooze on the south-west slope off Oahu, Hawaii, U.S.G.S. Open-File Report 82-468B.

Wyss, M., and Koyanagi, R., 1992. Isoseismal maps, macroseismic epicenters, and estimated magnitudes of historical earthquakes in the Hawaiian Islands: U.S. Geological Survey Bulletin 2006, 93 p.

Yuen, P.C., 1981. Ocean thermal energy conversion: a review, Hawaii Natural Energy Institute, University of Hawaii, Honolulu, 173 pp. 
Table 1. Submarine Cable Damage Descriptions associated with Hurricane Iwa November 23, 1982 (After Dengler and others, 1984b).

\begin{tabular}{|c|c|c|c|}
\hline $\begin{array}{c}\text { Cable } \\
\text { no. }\end{array}$ & Cable System & $\begin{array}{c}\text { Outage } \\
\text { Time(HST) }\end{array}$ & Remarks \\
\hline 1 & Hanauma Bay-Makahaa $^{*}$ & 1920 & Broken \\
\hline 2 & California-Makaha $^{a}$ & 1950 & Broken \\
\hline 3 & Guam-Makaha & & Broken \\
\hline 4 & Johnston Island-Makahab & 2000 & \\
\hline 5 & New Zealand-Keawaulac & 1940 & Damagedd $^{\text {c }}$ \\
\hline 6 & Vancouver-Keawaulac & 1940 & Brokend $^{c}$ \\
\hline
\end{tabular}

a Hawaiian Telephone Company/AT\&T

b Military

c Compac

d Damage occurred $15 \mathrm{~km}$ north of Kahe Point

*For a detailed history of AT\&T cable breaks in the Hawaiian Islands contact:

Carl Dinga AT\&T Ocean Surveys Planning Dept, (910)279-6230. 
Table 2. OTEC Study Core Station Information (calcareous ooze, after Winters and Lee, 1982).

\begin{tabular}{|c|c|c|c|}
\hline Station Number & $\begin{array}{c}\text { Longitude } \\
\text { Latitude }\end{array}$ & Water depth $(\mathrm{m})$ & Bottom slope $\left(^{\circ}\right)$ \\
\hline 1 & $\begin{array}{r}158^{\circ} 10.20^{\prime} \mathrm{W} \\
21^{\circ} 19.78^{\prime} \mathrm{N}\end{array}$ & 740 & 9.1 \\
\hline 2 & $\begin{array}{r}158^{\circ} 11.61^{\prime} \mathrm{W} \\
21^{\circ} 19.91^{\prime} \mathrm{N}\end{array}$ & 960 & 5.1 \\
\hline 6 & $\begin{array}{r}158^{\circ} 11.96^{\prime} \mathrm{W} \\
21^{\circ} 17.23^{\prime} \mathrm{N}\end{array}$ & 1110 & 6.6 \\
\hline 8 & $\begin{array}{r}158^{\circ} 11.01^{\prime} \mathrm{W} \\
21^{\circ} 16.44^{\prime} \mathrm{N}\end{array}$ & 1010 & 8.0 \\
\hline Average value & & & 7.2 \\
\hline
\end{tabular}


Table 3. Representative Engineering Properties of Sediment from Cores from the OTEC Study Area (after Winters and Lee, 1982).

\begin{tabular}{|c|c|c|c|c|c|c|c|}
\hline $\begin{array}{c}\text { Core } \\
\text { Number }\end{array}$ & $\mathrm{A}_{\mathrm{c}}$ & $\mathrm{A}_{\mathrm{r}}$ & $\mathrm{S}$ & $\mathrm{m}$ & $\begin{array}{c}\gamma \\
(\mathrm{kN} / \mathrm{m} 3)\end{array}$ & $\begin{array}{c}\gamma^{\prime} \\
(\mathrm{kN} / \mathrm{m} 3)\end{array}$ & $\phi\left(^{\circ}\right)$ \\
\hline 1 & 0.68 & 0.70 & 0.55 & 0.74 & 15.5 & 5.5 & 38 \\
\hline 2 & 0.65 & 0.74 & 0.49 & 0.87 & 15.0 & 5.0 & 36 \\
\hline 6 & 0.70 & 0.81 & 0.41 & 0.83 & 15.0 & 5.0 & 39 \\
\hline 8 & 0.70 & 0.78 & 0.54 & 0.80 & 15.0 & 5.0 & 39 \\
\hline $\begin{array}{c}\text { Average } \\
\text { value }\end{array}$ & 0.68 & 0.76 & 0.50 & 0.81 & 15.1 & 5.1 & 38 \\
\hline
\end{tabular}


Table 4. Fine-grained Terrigenous Sediment, Site Location.

\begin{tabular}{|c|c|c|}
\hline Station Number & $\begin{array}{c}\text { Longitude } \\
\text { Latitude }\end{array}$ & Water depth $(\mathrm{m})$ \\
\hline 15 & $\begin{array}{r}155^{\circ} 04.34^{\prime} \mathrm{W} \\
19^{\circ} 17.26^{\prime} \mathrm{N}\end{array}$ & 585 \\
\hline
\end{tabular}

Table 5. Representative Engineering Properties of a Fine-Grained Terrigenous Sediment.

\begin{tabular}{|c|c|c|c|c|c|c|}
\hline $\begin{array}{c}\text { Core } \\
\text { Number }\end{array}$ & $\mathrm{A}_{\mathrm{c}}$ & $\mathrm{A}_{\mathrm{r}}$ & $\mathrm{S}$ & $\begin{array}{c}\gamma \\
(\mathrm{kN} / \mathrm{m} 3)\end{array}$ & $\begin{array}{c}\gamma^{\prime} \\
(\mathrm{kN} / \mathrm{m} 3)\end{array}$ & $\phi\left(^{\circ}\right)$ \\
\hline $15 \mathrm{~B} 2$ & $\begin{array}{c}0.80 \\
\text { (assumed) }\end{array}$ & $0.66^{\star}$ & 0.43 & 1.72 & 0.72 & 37 \\
\hline
\end{tabular}

*Estimated from previous tests of similar material (Lee and Edwards, 1986). 
Table 6. Maximum Equilibrium Slopes (Angles of Repose) for Three General Hawaiian Sediment Types.

\begin{tabular}{|l|l|l|l|}
\hline Sediment Type & $\begin{array}{l}\text { Static Angle of } \\
\text { Repose }\end{array}$ & $\begin{array}{l}\text { Seismic Angle of } \\
\text { Repose }\end{array}$ & $\begin{array}{l}\text { Wave Loading } \\
\text { Angle of repose }\end{array}$ \\
\hline $\begin{array}{l}\text { Volcaniclastic } \\
\text { Sands (coarse } \\
\text { and angular) }\end{array}$ & $\begin{array}{l}25^{\circ}-40^{\circ} \text { (field } \\
\text { slopes) }\end{array}$ & $\begin{array}{l}10^{\circ}-15^{\circ} \text { (field } \\
\text { slopes near } \\
\text { Kilauea) }\end{array}$ & \\
\hline Calcareous Ooze & $\begin{array}{l}38^{\circ} \text { (lab samples)- } \\
30^{\circ}-40^{\circ} \text { (field } \\
\text { slopes) }\end{array}$ & $\begin{array}{l}7^{\circ} \text { (lab samples, } \\
\text { sites near Oahu) } \\
5^{\circ}-10^{\circ} \text { (field } \\
\text { slopes near } \\
\text { Oahu) }\end{array}$ & $<30^{\circ}-40^{\circ}$ \\
\hline $\begin{array}{l}\text { Fine-Grained } \\
\text { Terrigenous } \\
\text { sediment }\end{array}$ & $37^{\circ}$ (lab samples) & $\begin{array}{l}7^{\circ} \text { (lab samples, } \\
\text { sites near Oahu) } \\
\text { virtually level } \\
\text { ground (lab } \\
\text { samples, sites } \\
\text { near Kilauea) }\end{array}$ & \\
\hline
\end{tabular}

*Field data set not complete enough to evaluate this quantity with any degree of accuracy. 


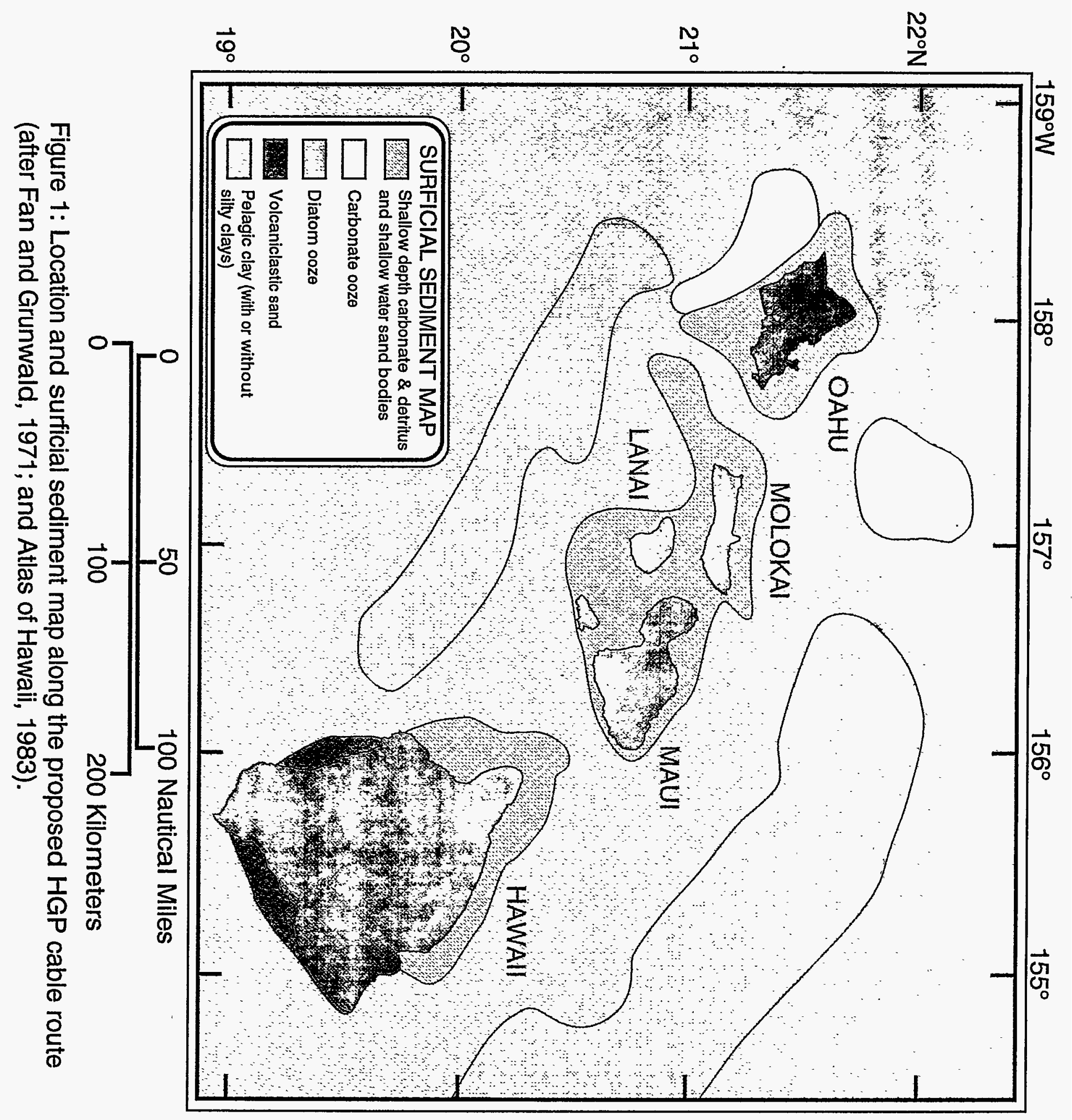




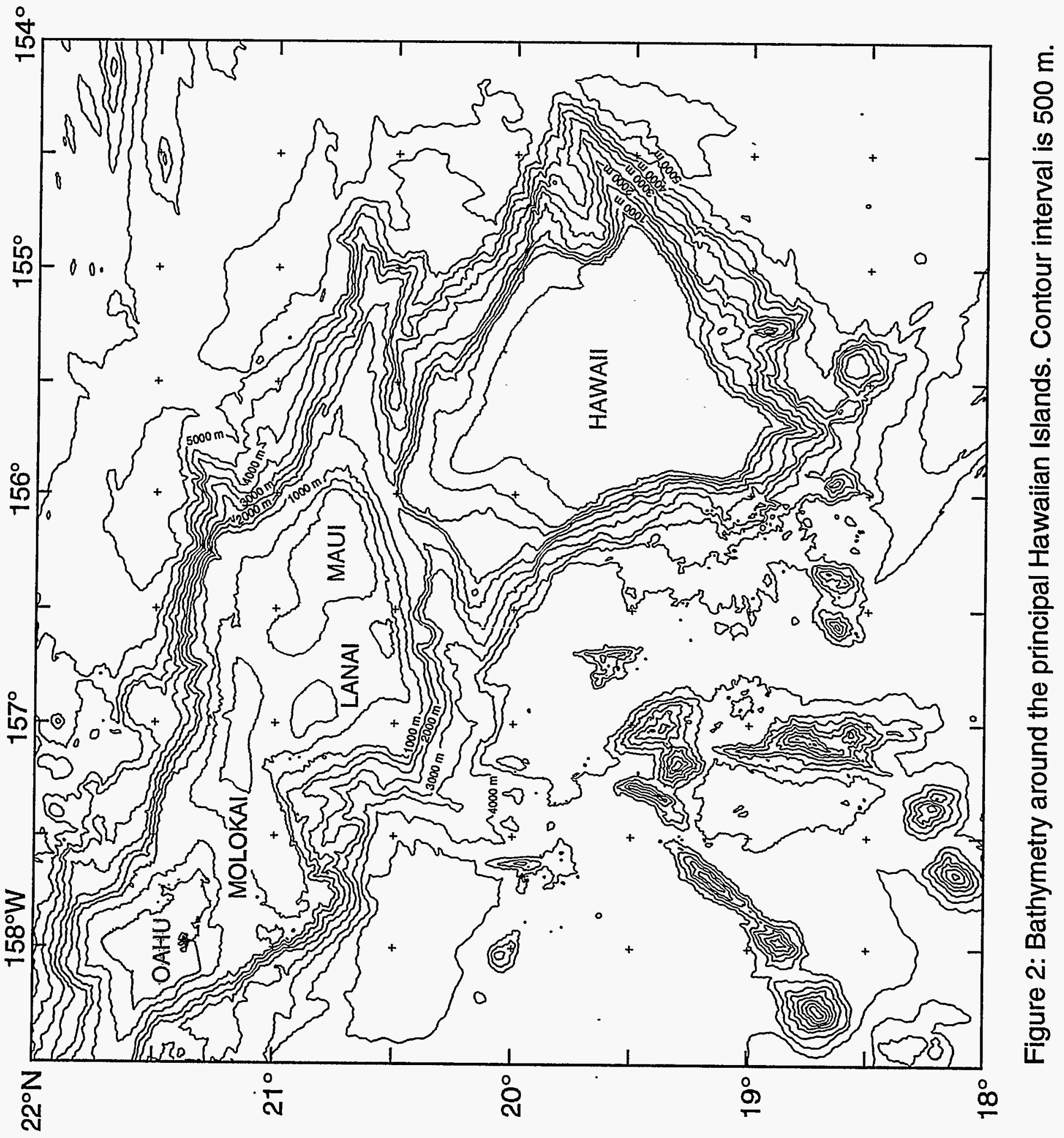




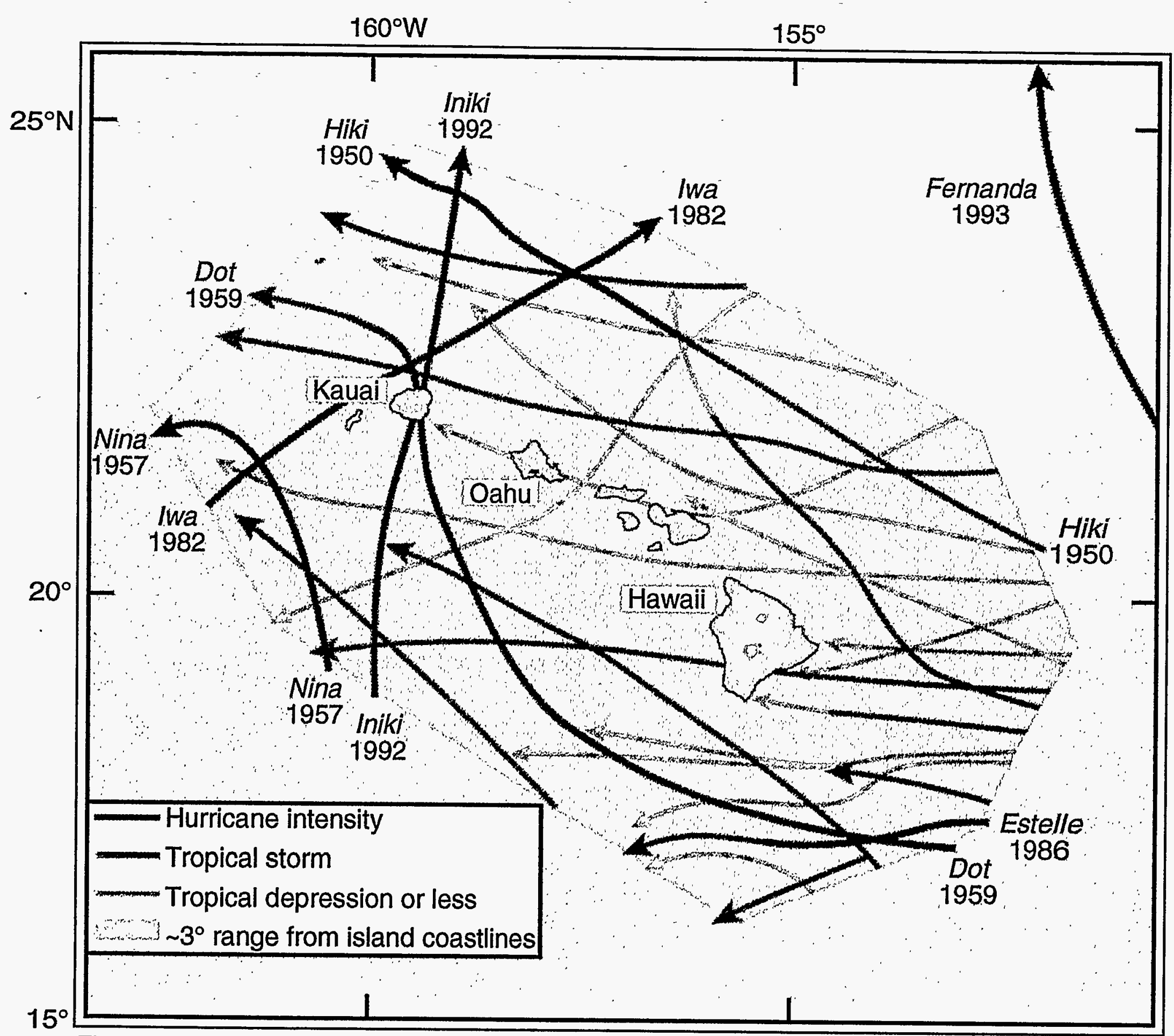

Figure 3: Storm Track Map for storms affecting the Hawailan Islands (after Schroeder, 1993; and Fletcher and others, in prep). 


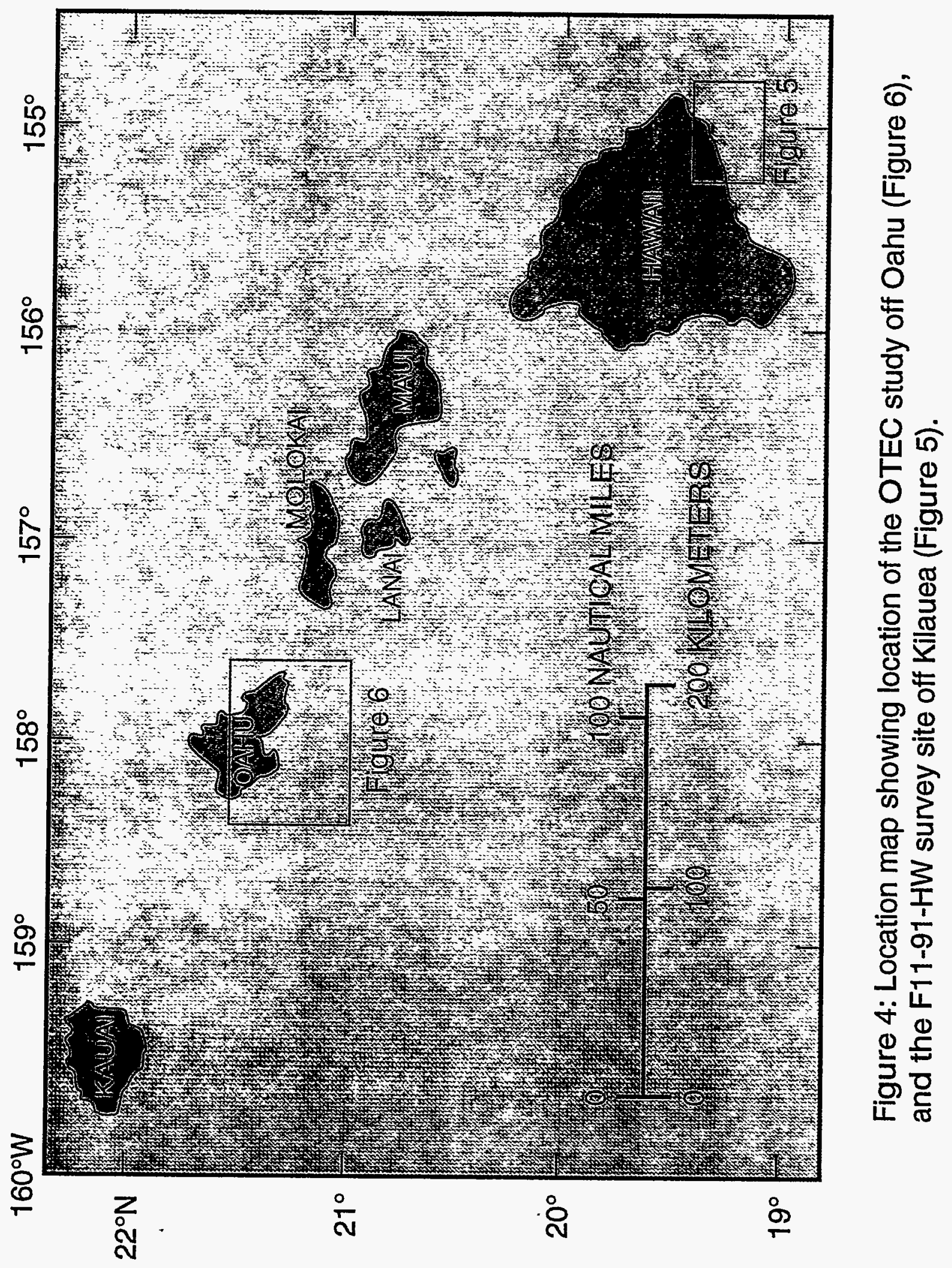




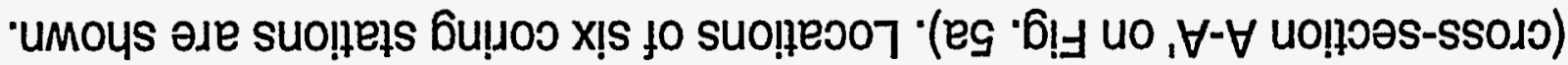

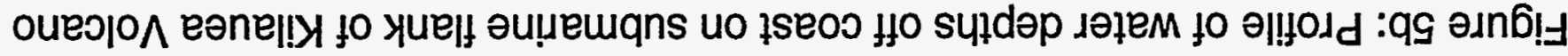

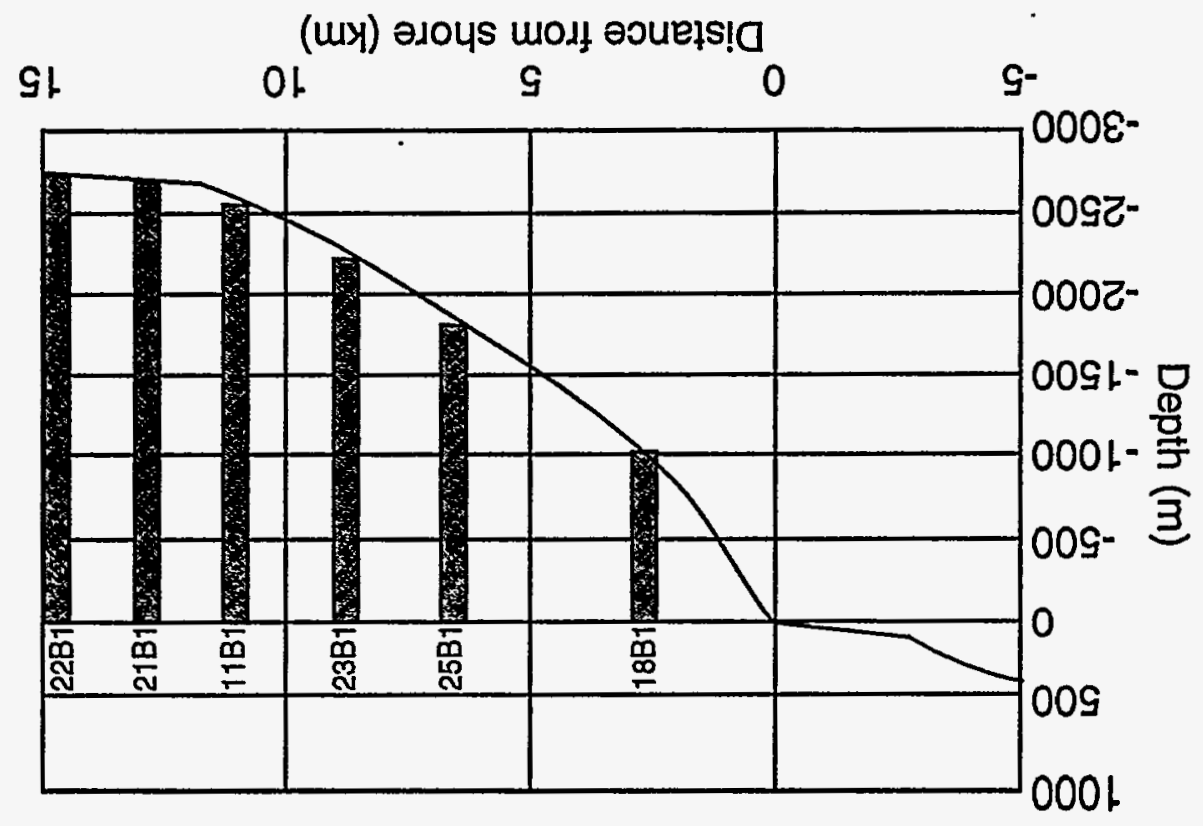

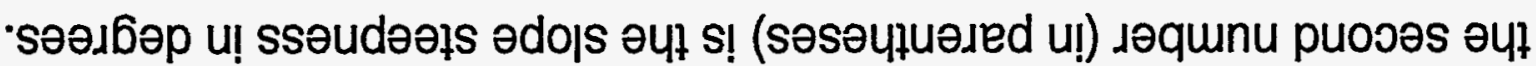

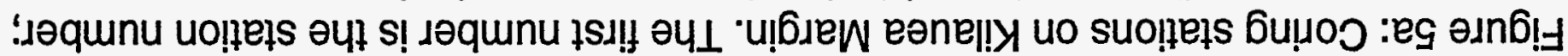

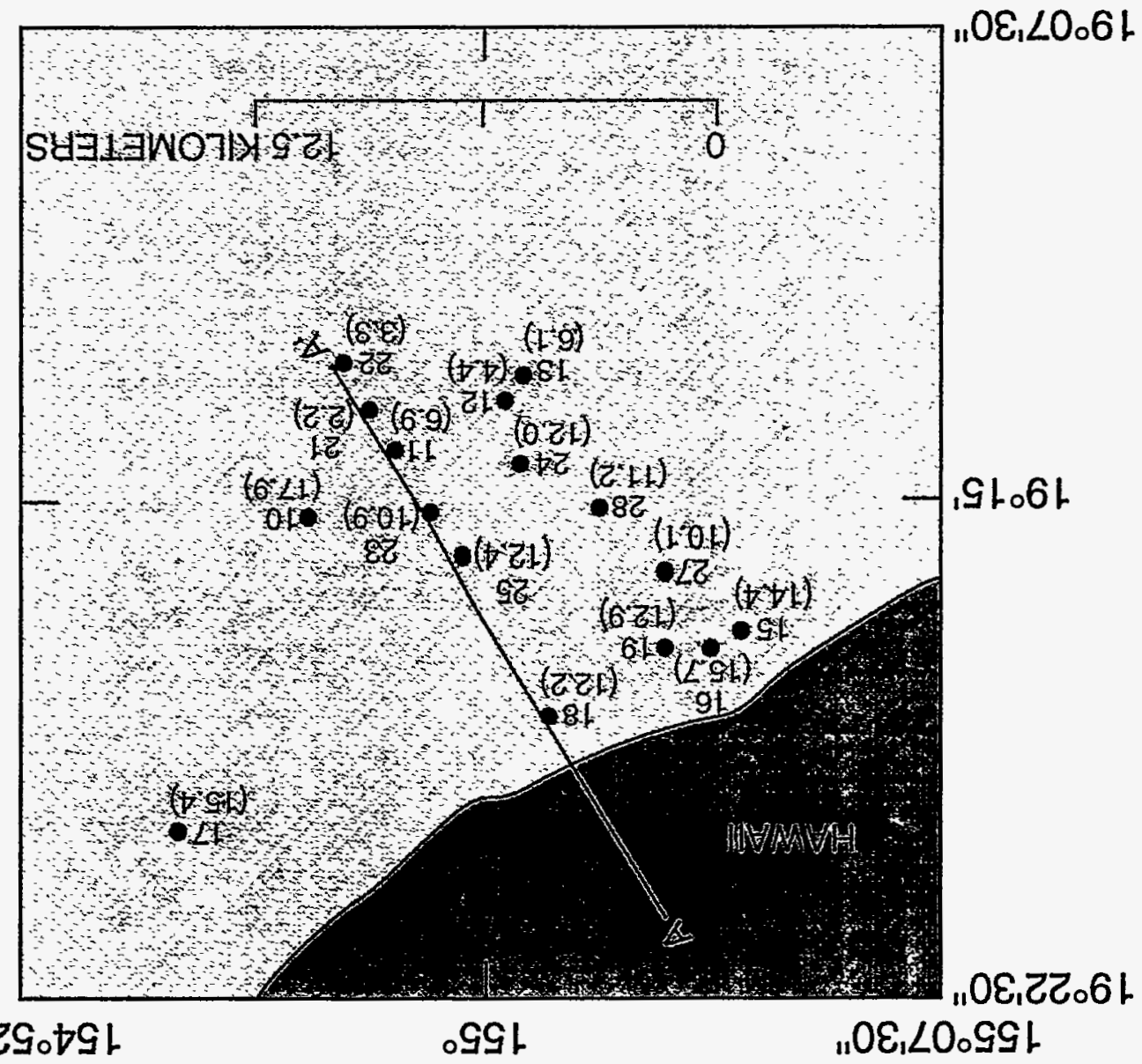




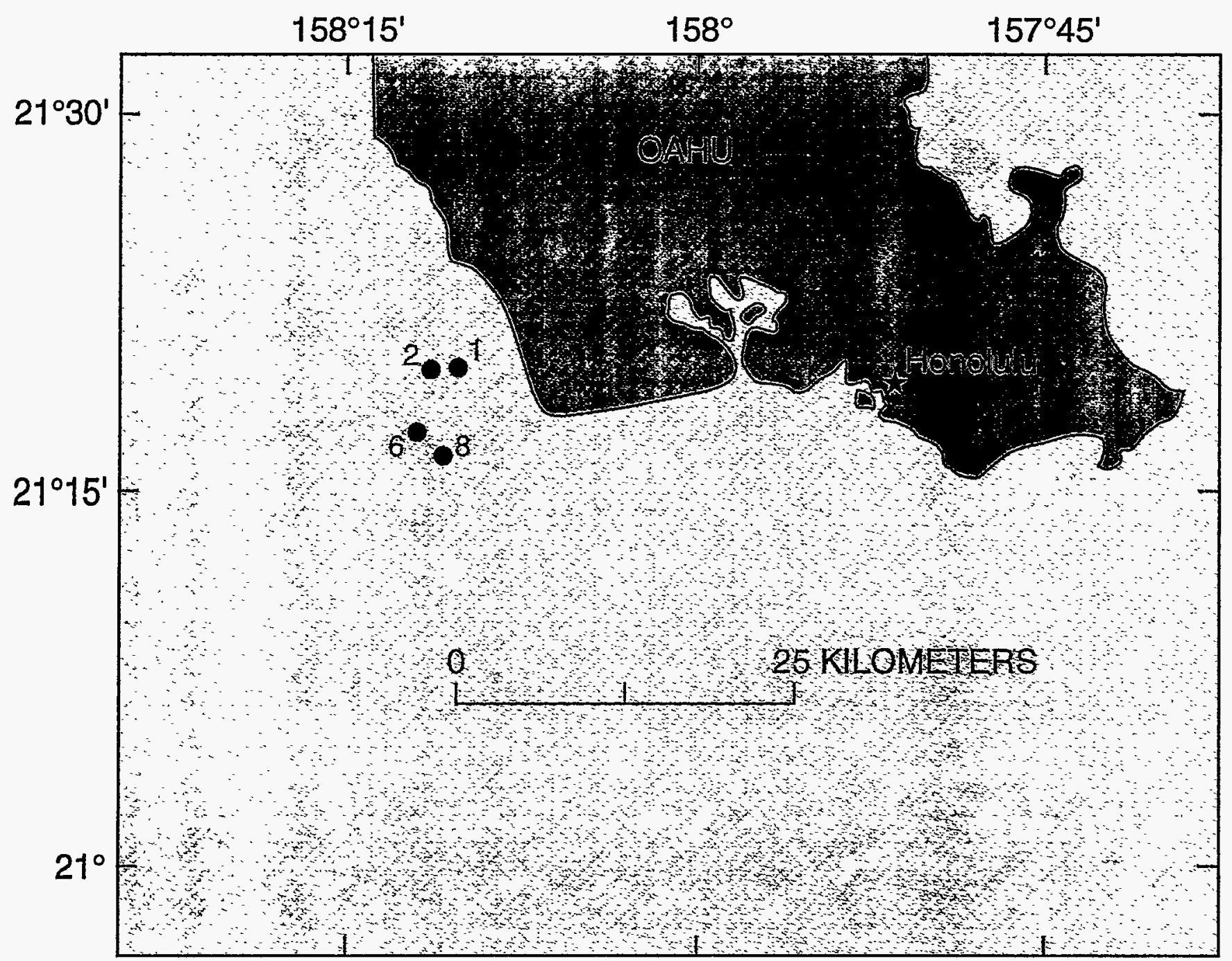

Figure 6: Location map for calcareous ooze stations (after Winters and Lee, 1982). 
Appendix 1: Station Locations, Box core descriptions, and selected physical properties of non-carbonate pelagic clay sediment from the Hawaiian EEZ.

Appendix 1 is a compilation of sediment core descriptions, grain size and other physical index properties from cores collected by the US Geological Survey, in association with the USGS Hawaiian EEZ-Scan surveys conducted between 1986 and 1991. The appendix is included to document the lower slope and basin terrigenous sediment type, its associated physical properties, and the existence of turbidites that are interlayered with the non-calcareous end member. Garcia and Hull (1994) show that turbidites, possibly associated with the giant landslides, were shed off the southwest flank of Mauna Loa and traveled up to $320 \mathrm{~km}$ from their source, climbing upslope over 500 meters in elevation. The energy involved in this type of sediment movement is likely catastrophic. These turbidites show that sediment gravity flows, regardless of initiation process, occur on Hawaiian submarine slopes, and pose a documented hazard to submarine cables. Sediment gravity flows such as that described off Kahe Point in association with Hurricane Iwa are a proven hazard to submarine cables in the Hawaiian Islands (Table 1). 


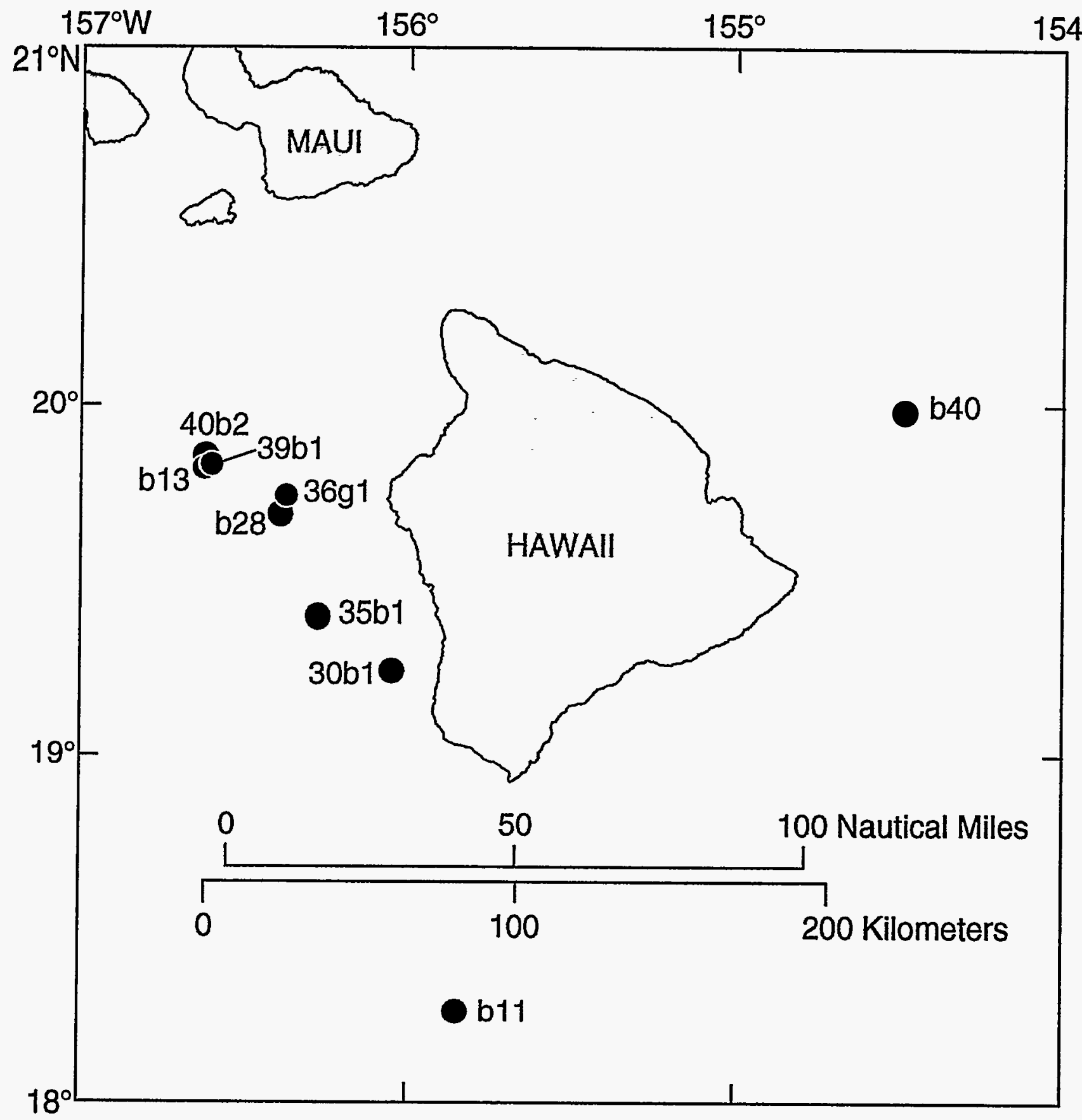

Figure A1: Location map of non-carbonate pelagic clay core samples taken from off the Island of Hawaii. 


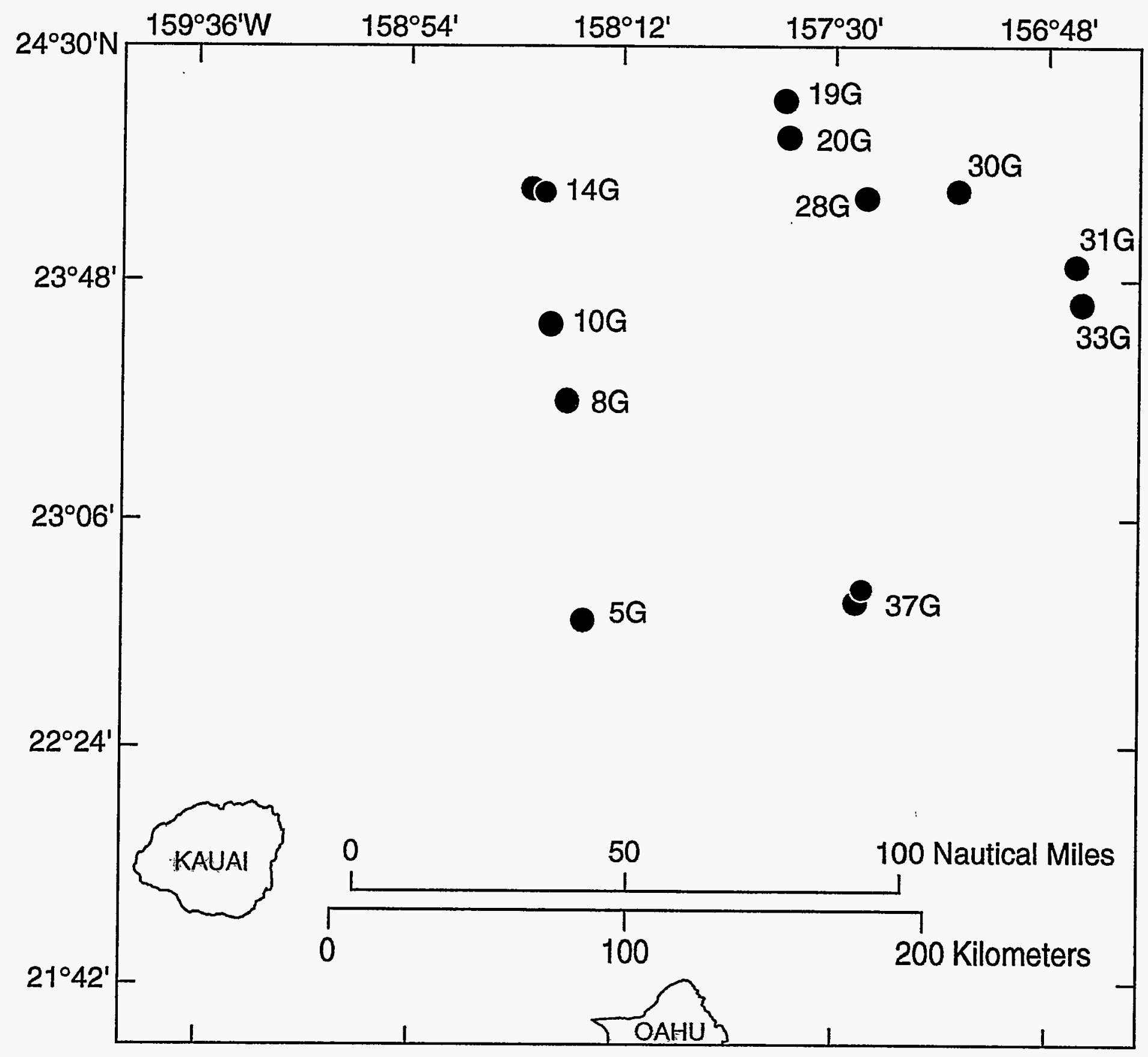

Figure A2: Location map of non-carbonate pelagic clay core samples collected from north of Oahu. 


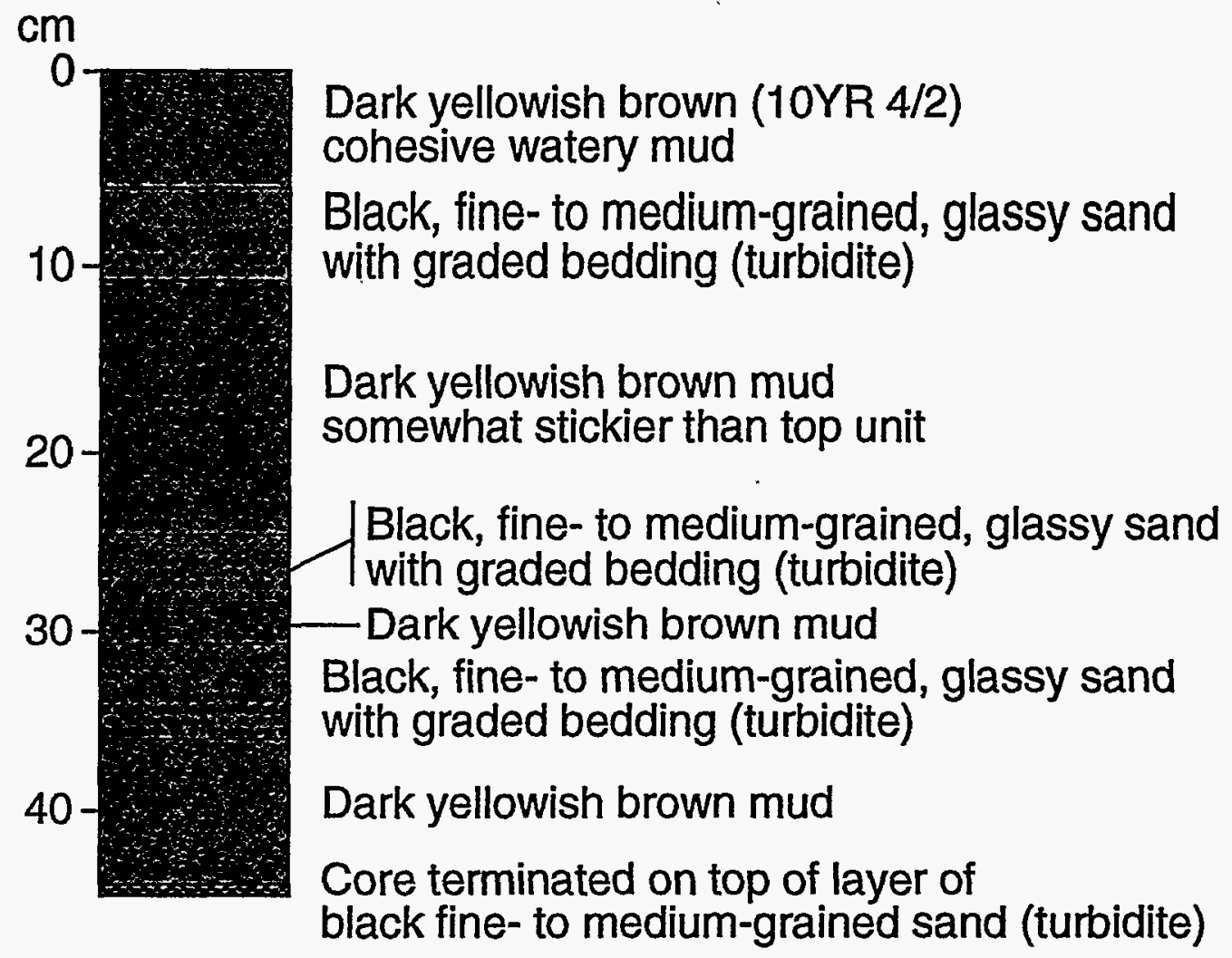

Figure A3: Stratigraphy of box core B11. 


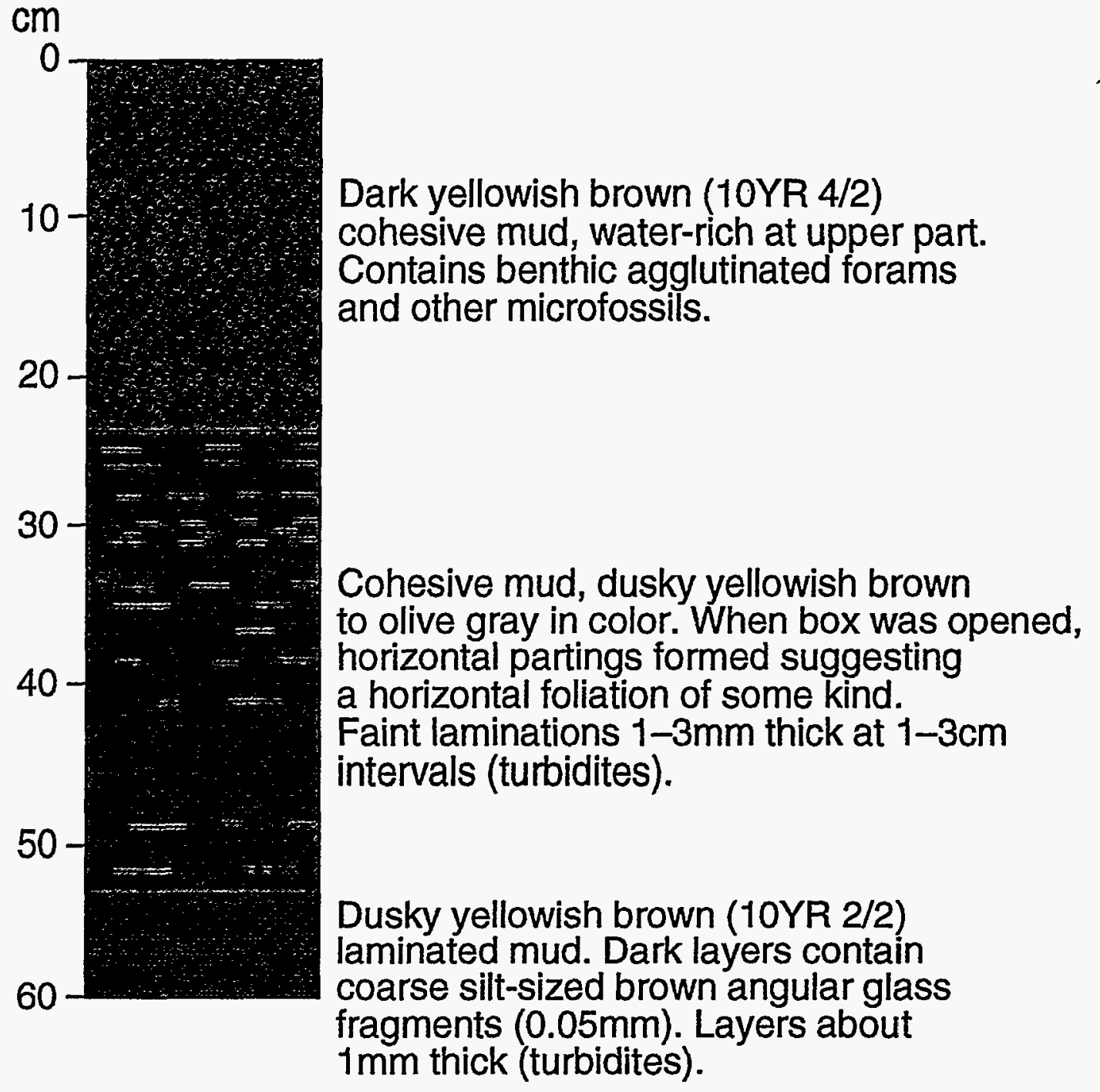

Figure A4: Stratigraphy of box core B13, $10 \mathrm{~km}$ northwest of toe, Alika slide. 


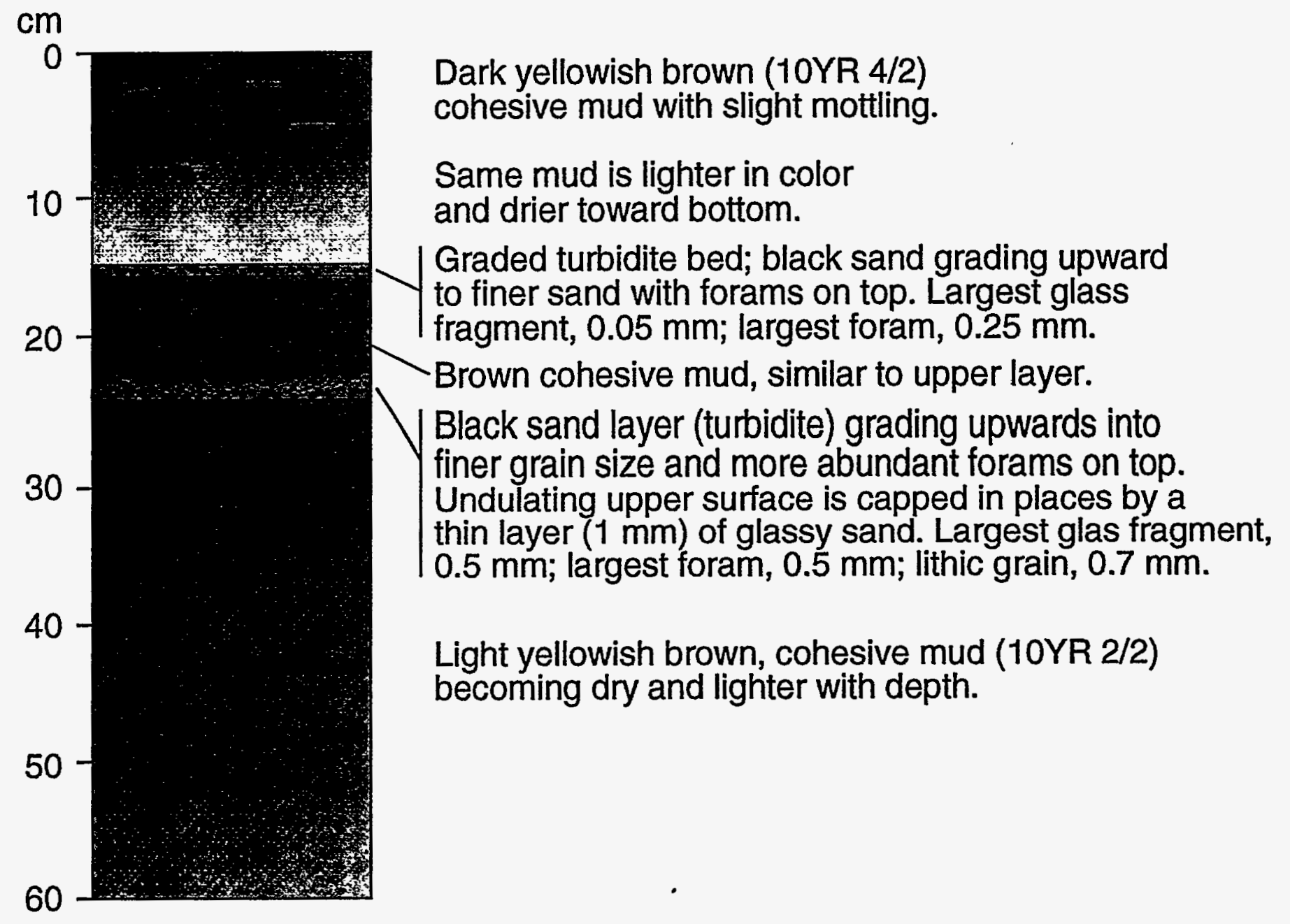

Figure A5: Stratigraphy of box core B28, on toe of Alika slide. 


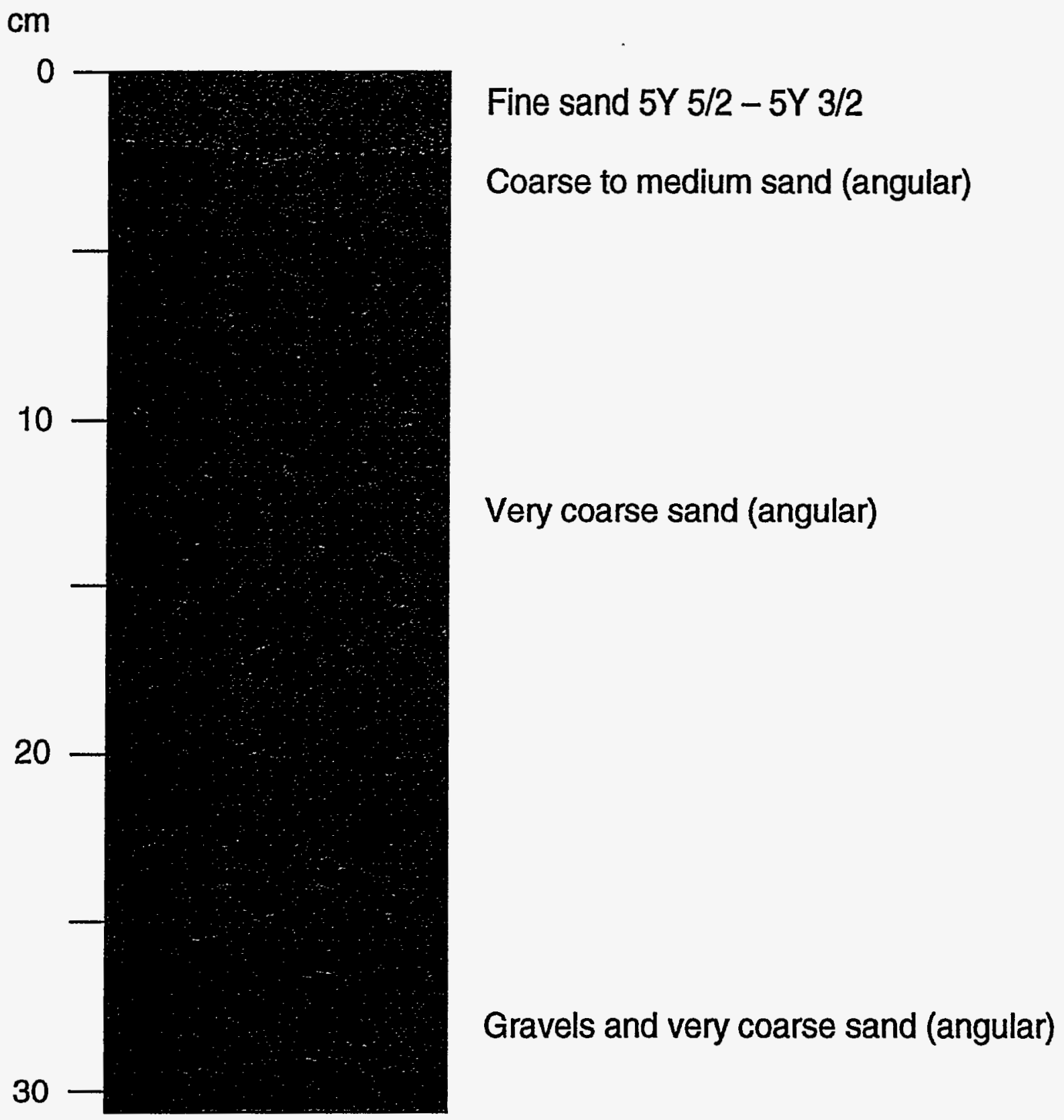

Figure A6: Stratigraphy of box core 30B1. 


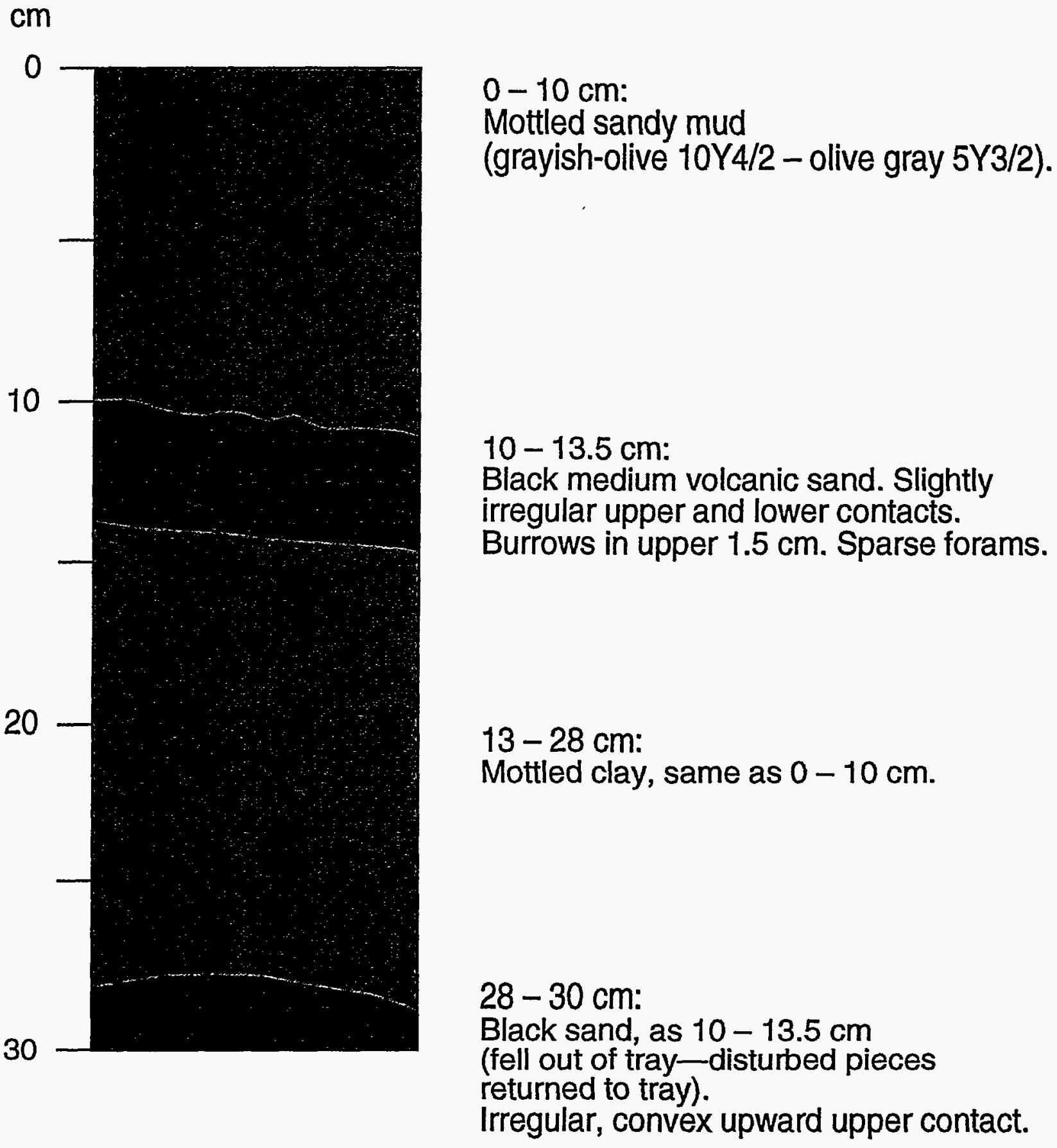

Figure A7: Stratigraphy of box core 35B1. 


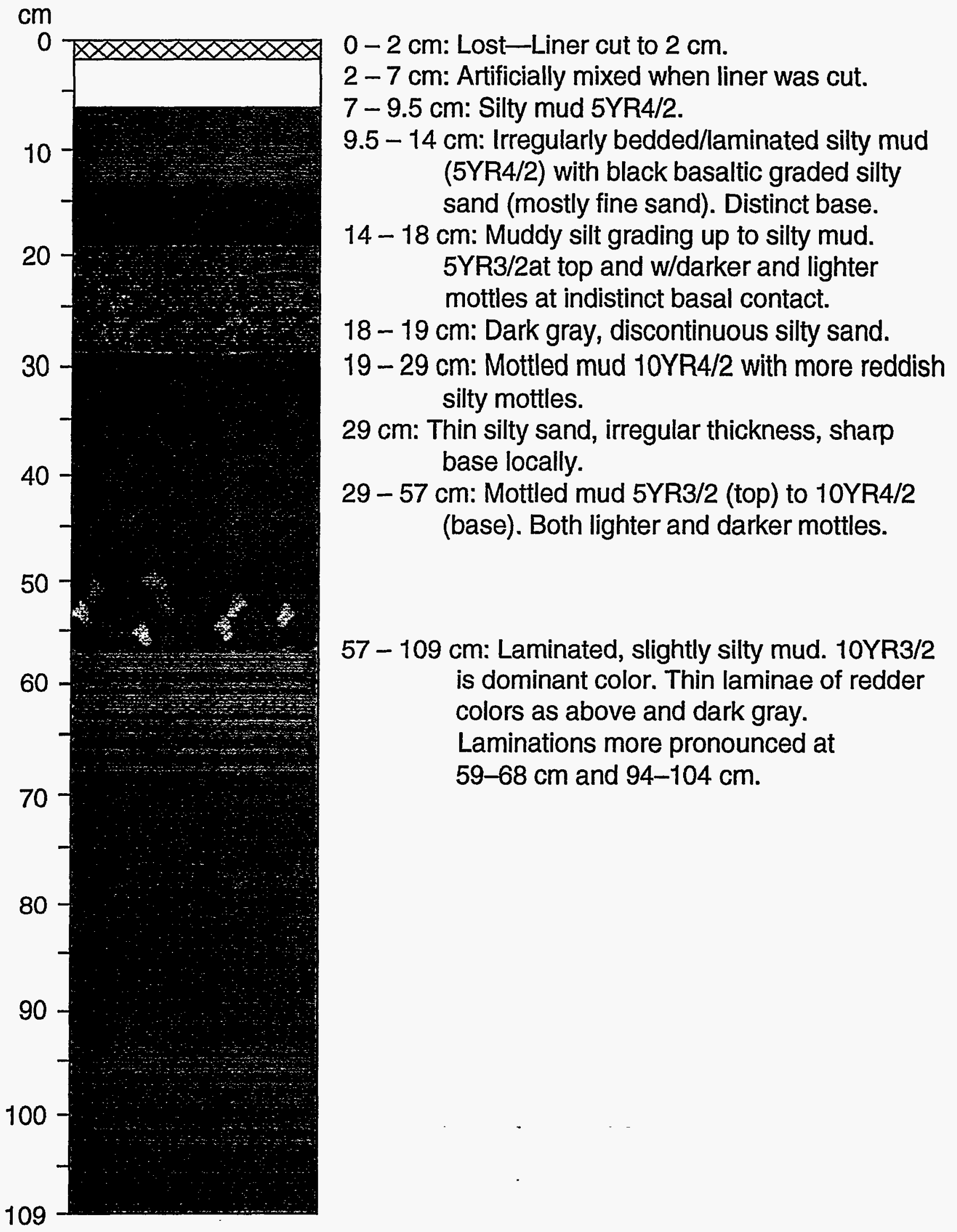

Figure A8: Stratigraphy of gravity core 36G. 


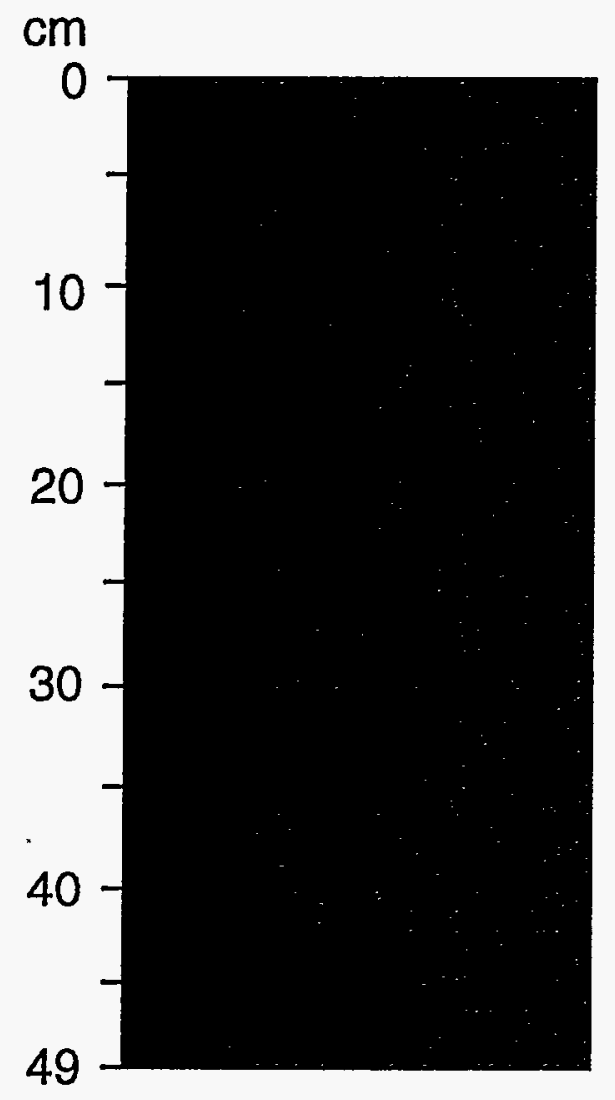

$0-10 \mathrm{~cm}: 5 \mathrm{YR} 3 / 3$

$12 \mathrm{~cm}$ : Gradational contact between less consolidated gray brown mud above and slightly mottled, slightly firmer mud below.

$12-29.5 \mathrm{~cm}: 5 Y R 3 / 4$

$29.5 \mathrm{~cm}$ : Disrupted $1 \mathrm{~mm}$ thick lamination, 10YR2/2. Several less distinct thicker units $(1-2.5 \mathrm{~mm})$ of similar color. Feels like fine silty laminae. Open burrow at $30.5 \mathrm{~cm}$.

$33-49 \mathrm{~cm}: 5 Y R 3 / 4$ mud with faint parallel lamination w/color similar to 10YR2/2.

Figure A9: Stratigraphy of box core 39B1. 


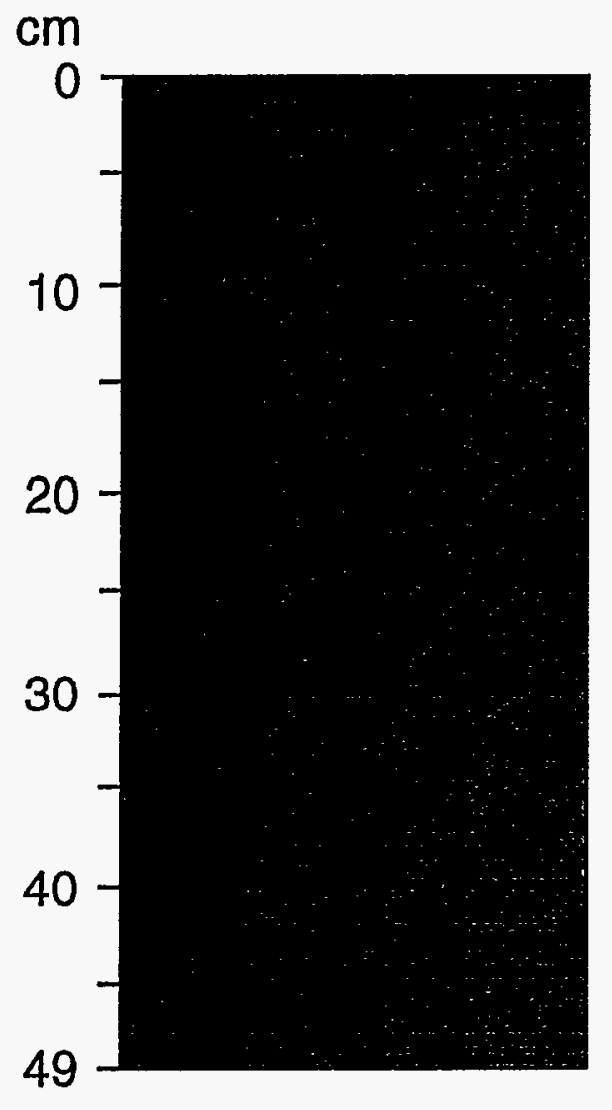

0-30 cm: Uniform texture, chocolate brown (5YR2/4) slightly silty mud that shows faint mottles only near base of unit at $30 \mathrm{~cm}$. Generally massive unit.

$30-37 \mathrm{~cm}$ : Slightly silty mud with faint mottles; main color 10YR4/2 and mottles are either slightly lighter or darker.

$37-49 \mathrm{~cm}$ : Slightly silty mud with faint laminations. Color is 10YR4/2 and laminations are slightly grayer-brown units (5YR3/2) up to $3 \mathrm{~mm}$ thick but generally $1-2 \mathrm{~mm}$.

Figure A10: Stratigraphy of box core 40B2. 
Table A1: Grain Size Distribution: Samples from Cruise F2-88-HW

\begin{tabular}{|c|c|c|c|c|c|c|c|}
\hline Sample ID & Interval (cm) & Depth (m) & Latitude & Longitude & $\%$ sand & $\%$ silt & \%clay \\
\hline F288HW-B11 & Surface & 4914 & $18^{\circ} 16.7 \mathrm{~N}$ & $155^{\circ} 48.9^{\prime} \mathrm{W}$ & 13.4 & 66.1 & 20.5 \\
\hline F288HW-B11 & $5-6$ & 4914 & $18^{\circ} 16.7 \mathrm{~N}$ & $155^{\circ} 48.9^{\circ} \mathrm{W}$ & 15.1 & 70.3 & 14.6 \\
\hline F288HW-B11 & $7-8$ & 4914 & $18^{\circ} 16.7 \mathrm{~N}$ & $155^{\circ} 48.9^{\top} \mathrm{W}$ & 87.8 & 12.0 & 0.2 \\
\hline F288HW-B11 & $8-10$ & 4914 & $18^{\circ} 16.7 \mathrm{~N}$ & $155^{\circ} 48.9^{\prime} \mathrm{W}$ & 89.3 & 9.8 & 0.9 \\
\hline F288HW-B11 & $10-12$ & 4914 & $18^{\circ} 16.7 \mathrm{~N}$ & $155^{\circ} 48.9^{\prime} \mathrm{W}$ & 8.4 & 67.1 & 24.6 \\
\hline F288HW-B11 & $22-25$ & 4914 & $18^{\circ} 16.7 \mathrm{~N}$ & $155^{\circ} 48.9^{\prime} \mathrm{W}$ & 16.6 & 72.9 & 10.6 \\
\hline F288HW-B11 & $25-26$ & 4914 & $18^{\circ} 16.7 \mathrm{~N}$ & $155^{\circ} 48.9^{\circ} \mathrm{W}$ & 88.1 & 11.4 & 0.5 \\
\hline F288HW-B11 & $26-27$ & 4914 & $18^{\circ} 16.7 \mathrm{~N}$ & $155^{\circ} 48.9^{\circ} \mathrm{W}$ & 93.9 & 6.3 & 0.3 \\
\hline F288HW-B11 & $28-29$ & 4914 & $18^{\circ} 16.7^{\prime} \mathrm{N}$ & $155^{\circ} 48.9^{\circ} \mathrm{W}$ & 21.8 & 69.9 & 8.4 \\
\hline F288HW-B11 & $30-32$ & 4914 & $18^{\circ} 16.7 \mathrm{~N}$ & $155^{\circ} 48.9^{\circ} \mathrm{W}$ & 29.5 & 64.0 & 6.5 \\
\hline F288HW-B11 & $32-34$ & 4914 & $18^{\circ} 16.7 \mathrm{~N}$ & $155^{\circ} 48.9^{\circ} \mathrm{W}$ & 94.6 & 5.6 & 0.3 \\
\hline F288HW-B11 & $37-39$ & 4914 & $18^{\circ} 16.7 \mathrm{~N}$ & $155^{\circ} 48.9^{\prime} \mathrm{W}$ & 17.7 & 68.3 & 14.1 \\
\hline F288HW-B11 & $50-52$ & 4914 & $18^{\circ} 16.7 \mathrm{~N}$ & $155^{\circ} 48.9^{\top} \mathrm{W}$ & 15.7 & 68.7 & 15.6 \\
\hline F288HW-B11 & 55 & 4914 & $18^{\circ} 16.7^{\prime} \mathrm{N}$ & $155^{\circ} 48.9^{\prime} \mathrm{W}$ & 90.1 & 9.0 & 0.9 \\
\hline F288HW-B13 & Surface & 4780 & $19^{\circ} 49.6^{\prime} \mathrm{N}$ & $156^{\circ} 40.2^{r} \mathrm{~W}$ & 4.2 & 65.6 & 30.2 \\
\hline F288HW-B13 & $2-3$ & 4780 & $19^{\circ} 49.6 \mathrm{~N}$ & $156^{\circ} 40.2^{\top} \mathrm{W}$ & 2.3 & 68.2 & 29.6 \\
\hline F288HW-B13 & $5-6$ & 4780 & $19^{\circ} 49.6 \mathrm{~N}$ & $156^{\circ} 40.2^{\prime} \mathrm{W}$ & 1.4 & 68.9 & 29.7 \\
\hline F288HW-B13 & $10-11$ & 4780 & $19^{\circ} 49.6 \mathrm{~N}$ & $156^{\circ} 40.2^{\prime} \mathrm{W}$ & 1.9 & 65.5 & 32.6 \\
\hline F288HW-B13 & $20-22$ & 4780 & $19^{\circ} 49.6^{\prime} \mathrm{N}$ & $156^{\circ} 40.2^{\circ} \mathrm{W}$ & 12 & 72.4 & 26.4 \\
\hline F288HW-B13 & 24 & 4780 & $19^{\circ} 49.6 \mathrm{~N}$ & $156^{\circ} 40.2^{\prime} \mathrm{W}$ & 1.6 & 71.3 & 27.2 \\
\hline F288HW-B13 & $30-32$ & 4780 & $19^{\circ} 49.6^{\prime} \mathrm{N}$ & $156^{\circ} 40.2 \mathrm{~W}$ & 5.2 & 75.0 & 19.7 \\
\hline F288HCW-B13 & $32-37$ & 4780 & $19^{\circ} 49.6^{\prime} \mathrm{N}$ & $156^{\circ} 40.2 \mathrm{~W}$ & 3.0 & 75.0 & 22.0 \\
\hline F288HW-B13 & 54-60. & 4780 & $19^{\circ} 49.6^{\prime} \mathrm{N}$ & $156^{\circ} 40.2^{\prime} \mathrm{W}$ & 23.5 & 68.8 & 7.7 \\
\hline F288HW-B13 & 60-bottom & 4780 & $19^{\circ} 49.6 \mathrm{~N}$ & $156^{\circ} 40.2^{\prime} \mathrm{W}$ & 33.1 & 61.7 & 5.2 \\
\hline F288HW-B28 & top & 4720 & $19^{\circ} 43.6^{\prime} \mathrm{N}$ & $156^{\circ} 24.1^{\prime} \mathrm{W}$ & 5.2 & 67.8 & 27.0 \\
\hline F288HW-B28 & $5-7$ & 4720 & $19^{\circ} 43.6 \mathrm{~N}$ & $156^{\circ} 24.1^{\prime} \mathrm{W}$ & 4.8 & 68.5 & 26.7 \\
\hline F288HW-B28 & $10-12$ & 4720 & $19^{\circ} 43.6^{\prime} \mathrm{N}$ & $156^{\circ} 24.1^{\prime} \mathrm{W}$ & 3.3 & 24.0 & 72.7 \\
\hline F288HW-B28 & $12.5-13$ & 4720 & $19^{\circ} 43.6 \mathrm{~N}$ & $156^{\circ} 24.1^{\prime} \mathrm{W}$ & 59.9 & 34.2 & 5.9 \\
\hline F288HW-B28 & $20-22$ & 4720 & $19^{\circ} 43.6^{\prime} \mathrm{N}$ & $156^{\circ} 24.1^{\prime} \mathrm{W}$ & 4.6 & 65.7 & 29.7 \\
\hline F288HW-B28 & $23.5-25.5$ & 4720 & $19^{\circ} 43.6 \mathrm{~N}$ & $156^{\circ} 24.1 \mathrm{~W}$ & 83.2 & 12.1 & 4.8 \\
\hline F288HW-B28 & $30-32$ & 4720 & $19^{\circ} \cdot 43.6 \mathrm{~N}$ & $156^{\circ} 24.1^{\prime} \mathrm{W}$ & 9.3 & 62.2 & 28.5 \\
\hline F288HW-B28 & $40-42$ & 4720 & $19^{\circ} 43.6 \mathrm{~N}$ & $156^{\circ} 24.1^{\top} \mathrm{W}$ & 4.3 & 65.4 & 30.3 \\
\hline
\end{tabular}




\begin{tabular}{|l|l|c|c|c|c|c|c|}
\hline Table A1 & Continued & & & & & & \\
\hline Sample/Core & Interval(cm) & Depth (m) & Latitude & Longitude & \% Sand & \% Silt & \% Clay \\
\hline F288HW-B28 & 60 -bottom & 4720 & $19^{\circ} 43.6 \mathrm{~N}$ & $156^{\circ} 24.1^{\prime} \mathrm{W}$ & 1.5 & 72.0 & 26.5 \\
\hline F288HW & $0-2$ & 5501 & $19^{\circ} 59.4^{\prime} \mathrm{N}$ & $154^{\circ} 26.4 \mathrm{~W}$ & 18.2 & 65.9 & 15.9 \\
\hline F288HW-B40 & $8-10$ & 5501 & $19^{\circ} 59.4 \mathrm{~N}$ & $154^{\circ} 26.4 \mathrm{~W}$ & 21.7 & 61.2 & 17.1 \\
\hline F288HW-B40 & $14-16$ & 5501 & $19^{\circ} 59.4 \mathrm{~N}$ & $154^{\circ} 26.4 \mathrm{~W}$ & 20.5 & 64.2 & 15.3 \\
\hline F288HW-B40 & $21-22.5$ & 5501 & $19^{\circ} 59.4 ' \mathrm{~N}$ & $154^{\circ} 26.4 \mathrm{~W}$ & 70.3 & 27.5 & 2.2 \\
\hline F288HW-B40 & $25-27.5$ & 5501 & $19^{\circ} 59.4 \mathrm{~N}$ & $154^{\circ} 26.4 \mathrm{~W}$ & 36.4 & 54.4 & 9.3 \\
\hline F288HW-B40 & $30-32$ & 5501 & $19^{\circ} 59.4^{\prime} \mathrm{N}$ & $154^{\circ} 26.4 \mathrm{~W}$ & 26.6 & 55.9 & 17.5 \\
\hline F288HW-B40 & $40-42$ & 5501 & $19^{\circ} 59.4 \mathrm{~N}$ & $154^{\circ} 26.4 \mathrm{~W}$ & 24.1 & 51.4 & 24.7 \\
\hline F288HW-B40 & $56-57.5$ & 5501 & $19^{\circ} 59.4{ }^{\prime} \mathrm{N}$ & $154^{\circ} 26.4 \mathrm{~W}$ & 69.2 & 27.9 & 2.9 \\
\hline
\end{tabular}


TABLE A2: Grain Size Distribution: Gravity Core Samples from

Cruise F11-88- HW

\begin{tabular}{|c|c|c|c|c|c|c|c|}
\hline Sample/Core & Interval $(\mathrm{cm})$ & Depth (m) & Latitude & Longitude & $\%$ Sand & $\%$ Silt & $\%$ Clay \\
\hline F1188HW-G5 & cc & 4775 & $22^{\circ} 48.1 \mathrm{~N}$ & $158^{\circ} 17.6^{\prime} \mathrm{W}$ & 3.1 & 60.1 & 36.8 \\
\hline F1188HW-G10 & $0-2$ & 4630 & $23^{\circ} 41.4 \mathrm{~N}$ & $158^{\circ} 27.3^{\prime} \mathrm{W}$ & 0.4 & 41.6 & 58.0 \\
\hline F1188HW-G10 & $80-82$ & 4630 & $23^{\circ} 41.4 \mathrm{~N}$ & $158^{\circ} 27.3^{\prime} \mathrm{W}$ & 1.4 & 47.2 & 51.4 \\
\hline F1188HW-G10 & $\mathrm{cc}$ & 4630 & $23^{\circ} 41.4 \mathrm{~N}$ & $158^{\circ} 27.3^{\prime} \mathrm{W}$ & 4.0 & 62.4 & 33.6 \\
\hline F1188HW-G14 & $0-2$ & 4615 & $23^{\circ} 41.4 \mathrm{~N}$ & $158^{\circ} 27.3^{\prime} \mathrm{W}$ & 0.2 & 35.4 & 64.3 \\
\hline F1188HW-G14 & $60-62$ & 4615 & $24^{\circ} 06.2 \mathrm{~N}$ & $158^{\circ} 28.2^{\prime} \mathrm{W}$ & 02 & 38.2 & 61.6 \\
\hline F1188HW-G14 & $113-115$ & 4615 & $24^{\circ} 06.2 \mathrm{~N}$ & $158^{\circ} 28.2^{\prime} \mathrm{W}$ & 0.3 & 39.8 & 59.9 \\
\hline F1188HW-G19 & $30-32$ & 4450 & $24^{\circ} 26.4 \mathrm{~N}$ & $157^{\circ} 38.3^{\prime} \mathrm{W}$ & 1.0 & 43.1 & 55.9 \\
\hline F1188HW-G19 & $174-176$ & 4450 & $24^{\circ} 26.4 \mathrm{~N}$ & $157^{\circ} 38.3^{\prime} \mathrm{W}$ & 0.7 & 33.8 & 65.5 \\
\hline F1188HW-G19 & $352-354$ & 4450 & $24^{\circ} 26.4 \mathrm{~N}$ & $157^{\circ} 38.3^{\prime} \mathrm{W}$ & 1.3 & 36.4 & 62.3 \\
\hline F1188HW-G20 & $0-2$ & 4372 & $23^{\circ} 49.6 \mathrm{~N}$ & $157^{\circ} 39.2^{\prime} \mathrm{W}$ & 0.2 & 33.9 & 65.9 \\
\hline F1188HW-G20 & $48-50$ & 4372 & $23^{\circ} 49.6 \mathrm{~N}$ & $157^{\circ} 39.2^{\prime} \mathrm{W}$ & 0.3 & 33.2 & 66.5 \\
\hline F1188HW-G20 & $95-97$ & 4372 & $23^{\circ} 49.6 \mathrm{~N}$ & $157^{\circ} 39.2^{\prime} \mathrm{W}$ & 0.6 & 34.4 & 64.9 \\
\hline F1188HW-G28 & $0-2$ & 4380 & $23^{\circ} 02.6 \mathrm{~N}$ & $157^{\circ} 21.3^{\prime} \mathrm{W}$ & 1.1 & 36.3 & 62.5 \\
\hline F1188HW-G28 & $60-62$ & 4380 & $23^{\circ} 02.6 \mathrm{~N}$ & $157^{\circ} 21.3^{\prime} \mathrm{W}$ & 0.4 & 32.2 & 67.4 \\
\hline F1188HW-G28 & $\mathrm{cc}$ & 4380 & $23^{\circ} 02.6 \mathrm{~N}$ & $157^{\circ} 21.3^{\prime} \mathrm{W}$ & 0.3 & 29.1 & 70.6 \\
\hline F1188HW-G30 & $0-2$ & 4375 & $24^{\circ} 04.9 \mathrm{~N}$ & $157^{\circ} 04.7^{\prime} \mathrm{W}$ & 0.6 & 39.8 & 59.6 \\
\hline F1188HW-G30 & $30-32$ & 4375 & $24^{\circ} 04.9 \mathrm{~N}$ & $157^{\circ} 04.7^{\prime} \mathrm{W}$ & 0.6 & 36.3 & 63.2 \\
\hline F1188HW-G30 & $60-62$ & 4375 & $24^{\circ} 04.9 \mathrm{~N}$ & $157^{\circ} 04.7^{\prime} \mathrm{W}$ & 1.5 & 33.8 & 64.6 \\
\hline F1188HW-G30 & $70-72$ & 4375 & $24^{\circ} 04.9 \mathrm{~N}$ & $157^{\circ} 04.7^{\prime} \mathrm{W}$ & 1.7 & 36.9 & 61.4 \\
\hline F1188HW-G30 & $90-92$ & 4375 & $24^{\circ} 04.9 \mathrm{~N}$ & $157^{\circ} 04.7^{\prime} \mathrm{W}$ & 4.9 & 38.1 & 56.9 \\
\hline F1188HW-G30 & $98-100$ & 4375 & $24^{\circ} 04.9^{\prime} \mathrm{N}$ & $157^{\circ} 04.7^{\prime} \mathrm{W}$ & 6.8 & 37.2 & 56.0 \\
\hline F1188HW-G30 & $120-122$ & 4375 & $24^{\circ} 04.9 \mathrm{~N}$ & $157^{\circ} 04.7^{\prime} \mathrm{W}$ & 1.1 & 37.1 & 61.8 \\
\hline F1188HW-G30 & $150-152$ & 4375 & $24^{\circ} 04.9 \mathrm{~N}$ & $157^{\circ} 04.7^{\prime} \mathrm{W}$ & 2.7 & 35.6 & 61.7 \\
\hline F1188HW-G30 & $180-182$ & 4375 & $24^{\circ} 04.9 \mathrm{~N}$ & $157^{\circ} 04.7^{\prime} \mathrm{W}$ & 12 & 44.2 & 54.7 \\
\hline F1188HW-G30 & $210-212$ & 4375 & $24^{\circ} 04.9 \mathrm{~N}$ & $157^{\circ} 04.7^{\prime} \mathrm{W}$ & 6.2 & 49.1 & 44.6 \\
\hline F1188HW-G30 & $240-242$ & 4375 & $24^{\circ} 04.9 \mathrm{~N}$ & $157^{\circ} 04.7^{\prime} \mathrm{W}$ & 1.3 & 45.7 & 52.9 \\
\hline F1188HW-G30 & $\mathrm{cc}$ & 4375 & $24^{\circ} 04.9 \mathrm{~N}$ & $157^{\circ} 04.7^{\prime} \mathrm{W}$ & 2.2 & 43.4 & 54.4 \\
\hline F1188HW-G31 & $0-2$ & 4295 & $23^{\circ} 50.5 \mathrm{~N}$ & $156^{\circ} 40.9^{\prime} \mathrm{W}$ & 1.0 & 40.9 & 58.1 \\
\hline F1188HW-G31 & $173-175$ & 4295 & $23^{\circ} 50.5 \mathrm{~N}$ & $156^{\circ} 40.9^{\prime} \mathrm{W}$ & 0.2 & 38.6 & 61.2 \\
\hline F1188HW-G31 & $\mathrm{cc}$ & 4295 & $23^{\circ} 50.5 \mathrm{~N}$ & $156^{\circ} 40.9^{\prime} \mathrm{W}$ & 0.6 & 50.6 & 48.8 \\
\hline
\end{tabular}




\begin{tabular}{|l|l|c|c|c|c|c|c|}
\hline Table A2 & Continued & & & & & & \\
\hline Sample/Core & Interval(cm) & Depth(m) & Latitude & Longitude & \%Sand & \%Silt & \%Clay \\
\hline F1188HW-G37 & $107-109$ & 4505 & $22^{\circ} 51.8 \mathrm{~N}$ & $157^{\circ} 22.3^{\prime} \mathrm{W}$ & 1.0 & 42.8 & 56.2 \\
\hline F1188HW-G37 & cc & 4505 & $22^{\circ} 51.8 \mathrm{~N}$ & $157^{\circ} 22.3^{\prime} \mathrm{W}$ & 5.6 & 61.0 & 33.3 \\
\hline F1188HW-G38 & $167-169$ & 4505 & $22^{\circ} 51.7 \mathrm{~N}$ & $157^{\circ} 24.0^{\prime} \mathrm{W}$ & 0.7 & 59.4 & 40.0 \\
\hline F1188HW-G38 & cc & 4505 & $22^{\circ} 51.7 \mathrm{~N}$ & $157^{\circ} 24.0^{\prime} \mathrm{W}$ & 2.4 & 54.2 & 43.4 \\
\hline F1188HW-G39 & $12-14$ & 4545 & $22^{\circ} 47.7 \mathrm{~N}$ & $157^{\circ} 26.1^{\prime} \mathrm{W}$ & 1.2 & 56.4 & 42.5 \\
\hline F1188HW-G39 & $167-169$ & 4545 & $22^{\circ} 47.7 \mathrm{~N}$ & $157^{\circ} 26.1^{\prime} \mathrm{W}$ & 0.7 & 63.6 & 35.7 \\
\hline F1188HW-G39 & $\mathrm{cc}$ & 4545 & $22^{\circ} 47.7 \mathrm{~N}$ & $157^{\circ} 26.1 \mathrm{~W}$ & 5.1 & 56.4 & 38.5 \\
\hline
\end{tabular}


Table A3: Representative water content data from non-carbonate pelagic sediment from north of Oahu, collected on cruise F11-88-HW.

\begin{tabular}{|c|c|c|}
\hline Core & interval (cm) & water content (\% dry wt) \\
\hline $5 G$ & $0-2$ & 128.65 \\
\hline $5 G$ & $10-12$ & 95.92 \\
\hline $5 G$ & $20-22$ & 91.06 \\
\hline $5 G$ & $30-33$ & 93.58 \\
\hline $5 G$ & $40-42$ & 95.70 \\
\hline $5 G$ & $50-52$ & 93.93 \\
\hline $5 G$ & $60-62$ & 101.08 \\
\hline $5 \mathrm{G}$ & $70-72$ & 98.12 \\
\hline $5 G$ & $80-82$ & 106.46 \\
\hline $5 \mathrm{G}$ & $90-92$ & 103.77 \\
\hline $5 G$ & $100-102$ & 99.99 \\
\hline $5 G$ & $110-112$ & 104.80 \\
\hline $5 \mathrm{G}$ & $120-122$ & 99.10 \\
\hline $5 G$ & $130-132$ & 129.39 \\
\hline $5 \mathrm{G}$ & $140-142$ & 249.62 \\
\hline $10 G$ & 5.0 & 123.34 \\
\hline $10 \mathrm{G}$ & $20-22$ & 86.77 \\
\hline $10 G$ & $30-33$ & 84.28 \\
\hline $10 \mathrm{G}$ & $40-42$ & 94.80 \\
\hline $10 \mathrm{G}$ & $50-52$ & 119.41 \\
\hline $10 G$ & $60-62$ & 115.06 \\
\hline $10 G$ & 70-72 & 91.86 \\
\hline $10 G$ & $80-82$ & 110.24 \\
\hline $10 G$ & $90-92$ & 161.37 \\
\hline $10 G$ & $100-102$ & 132.62 \\
\hline $10 G$ & $120-122$ & 138.64 \\
\hline $10 G$ & $140-142$ & 101.55 \\
\hline $10 G$ & $160-162$ & 89.58 \\
\hline $10 G$ & $168-170$ & 105.73 \\
\hline
\end{tabular}




\begin{tabular}{|c|c|c|}
\hline TABLE A3 & Continued & \\
\hline Core & Interval (cm) & $W_{C}$ (\% dry wt) \\
\hline $14 G$ & $0-2$ & 133.29 \\
\hline $14 G$ & $20-22$ & 99.53 \\
\hline $14 \mathrm{G}$ & $40-42$ & 93.09 \\
\hline $14 G$ & $60-62$ & 98.23 \\
\hline $14 G$ & $80-82$ & 85.19 \\
\hline $14 G$ & $100-102$ & 99.74 \\
\hline $14 G$ & $113-115$ & 90.98 \\
\hline $19 G$ & $30-32$ & 141.21 \\
\hline $19 G$ & $40-42$ & 107.56 \\
\hline $19 G$ & $60-62$ & 157.96 \\
\hline $19 G$ & $80-82$ & 113.33 \\
\hline $19 G$ & $100-102$ & 95.62 \\
\hline $19 G$ & $120-122$ & 118.03 \\
\hline $19 G$ & $174-176$ & 101.63 \\
\hline $19 G$ & $194-196$ & 105.01 \\
\hline $19 G$ & 214-216 & 126.41 \\
\hline $19 G$ & $234-236$ & 97.97 \\
\hline $19 G$ & $254-256$ & 94.99 \\
\hline $19 G$ & $274-276$ & 139.51 \\
\hline $19 G$ & 294-296 & 142.91 \\
\hline $19 G$ & $314-316$ & 94.66 \\
\hline $19 G$ & $392-394$ & 94.17 \\
\hline
\end{tabular}


Table A4: Representative Vane shear data and sediment classification from F11-91-HW cores collected off the west flank of Mauna Loa, at the toe of the Alika Slide.

\begin{tabular}{|c|c|c|c|c|}
\hline Core & Depth (cm) & $\begin{array}{c}\text { Original vane } \\
\text { shear strength, } \mathrm{S}_{\mathrm{u}} \\
(\mathrm{kPa}) \\
\end{array}$ & $\begin{array}{c}\text { Remolded vane } \\
\text { shear strength, } S_{r} \\
(\mathrm{kPa})\end{array}$ & Sensitivity, $S_{t}$ \\
\hline 35B1 & 6 & 3.4/very soft & 0.3 & 10.3/slightly quick \\
\hline $35 \mathrm{~B} 1$ & 16 & $5.6 /$ very soft & 1.2 & 4.9/very sensitive \\
\hline 35B1 & 25 & $15.1 / \mathrm{soft}$ & 1.6 & 9.2/slightly quick \\
\hline $36 \mathrm{G} 1$ & 35 & 3.8/very soft & 0.0 & 0 \\
\hline $36 \mathrm{G} 1$ & 45 & 4.0/very soft & 0.7 & 6.1/very sensitive \\
\hline $36 \mathrm{G} 1$ & 55 & 4.1/very soft & 1.2 & 3.6/med. sensitive \\
\hline $36 \mathrm{G1}$ & 65 & $8.4 /$ very soft & 1.1 & $7.8 /$ very sensitive \\
\hline $36 \mathrm{G} 1$ & 75 & $8.9 / v e r y$ soft & 1.9 & 4.7/very sensitive \\
\hline $36 \mathrm{G1}$ & 85 & $8.9 /$ very soft & 2.1 & 4.2/very sensitive \\
\hline $36 \mathrm{G} 1$ & 95 & 9.6/very soft & 1.8 & 5.3/very sensitive \\
\hline 39B1 & 5 & $1.7 /$ very soft & 0.7 & 2.3/med. sensitive \\
\hline 39B1 & 15 & 4.0/very soft & 1.0 & 4.1/very sensitive \\
\hline 39B1 & 25 & $6.6 /$ very soft & 1.2 & 5.7/very sensitive \\
\hline 39B1 & 35 & $10.9 /$ very soft & 1.2 & 8.8/slightly quick \\
\hline $39 \mathrm{~B} 1$ & 45 & $8.2 /$ very soft & 1.6 & 5.0/very sensitive \\
\hline $40 \mathrm{B2}$ & 5 & $1.2 /$ very soft & 0.3 & 3.5/med. sensitive \\
\hline $40 B 2$ & 12 & 4.1/very soft & 1.0 & 4.2/very sensitive \\
\hline $40 \mathrm{~B} 2$ & 20 & $4.9 /$ very soft & 1.6 & 3.0/med. sensitive \\
\hline $40 \mathrm{B2}$ & 30 & $6.0 /$ very soft & 1.9 & 3.2/med. sensitive \\
\hline $40 \mathrm{~B} 2$ & 40 & 11.0/very soft & 1.8 & 6.1/very sensitive \\
\hline
\end{tabular}




\section{GLOSSARY OF GEOTECHNICAL TERMS}

$\underline{A}_{c}:$ The factor $A_{c}$ accounts for sample preparation conditions applied in the laboratory.

$\underline{A}_{r}:$ The cyclic-strength degradation factor. This factor relates to the proportion of the shear strength that remains after earthquake shaking and resulting porewater pressure increase. Measured in the laboratory using cyclic strength testing.

Angle of Repose: The maximum slope angle (measured from horizontal) at which a soil or sediment will come to rest. The angle is typically somewhat less than the slope at which sliding will be initiated, and somewhat less than the Angle of Internal Friction $(\phi)$. The angle of repose depends on the frictional properties of the material and the nature of environmental loads (seismicity and storm environment). It commonly increases slightly as the size and angularity of the sediment particles increases.

Effective Stress $(\sigma)$ : Total stresses acting on a point on the seafloor minus the pressure in the pore water. $\left(\sigma_{n}{ }^{\prime}\right)=$ normal effective stress.

Friction Angle $(\phi)$ : Angle of internal friction; $\tan \phi=\tau_{f} / \sigma_{n}{ }^{\prime}$; The basic factor responsible for the strength of a sediment is the frictional resistance between soil particle in contact. The magnitude of this resistance, for a given sediment type depends on: the size and shape of the sediment particles; effective stress $(\sigma)$; whether the sediment is cohesionless or cohesive (sand or clay); relative density; and drainage conditions.

k: An empirical seismic acceleration factor, expressed in g's, or multiples of the gravitational acceleration. Derived from observed existing landslides in seismically active areas and used to predict future landslides in similar environments.

Overconsolidation Ratio (OCR): The ratio of maximum past effective stress to present overburden effective stress. 
S: The ratio of "undrained shear strength to consolidation stress for normal consolidation". Measured in the laboratory and ranges from values of 1.0 or higher for sands and coarse silts to values of 0.3 or lower for clayey silts and clays.

Semi-infinite slope: A plane surface that has a constant gradient $(\alpha)$ everywhere, and extends for an infinite distance upslope, downslope and along slope.

Shear Stress $(\tau)$ : Force per unit area along a flat surface. Seismically induced shear stress $=\tau_{\mathrm{s}}$. Shear stress induced by wave loading $=\tau_{w}$.

Shear Strength $\left(\tau_{f}\right)$ : Resistance to sliding along a particular plane.

Shear strength under repeated loading $\left(\mathrm{s}_{\mathrm{ur}}\right)$ : Shearing resistance when loading is applied cyclically

Submerged Density $\left(\gamma^{\prime}\right)$ : Total density minus the density of sea water.

Total Sediment Density(y): Total weight of sediment per unit volume.

z: depth below the sediment-water interface. 


\section{ACKNOWLEDGEMENTS}

The authors would like to thank the U.S.Geological Survey and the U.S. Department of Energy for sponsoring this study. We also want to extend a special thanks to Laura L. Zink, who drafted the figures, and Herman Karl, William Normark, Manuel Nathenson, and a Department of Energy reviewer for thoughtful discussions and critical reviews of the manuscript.

\section{DISCLAIMER}

This report was prepared as an account of work sponsored by an agency of the United States Government. Neither the United States Government nor any agency thereof, nor any of their employees, makes any warranty, express or implied, or assumes any legal liability or responsibility for the accuracy, completeness, or usefulness of any information, apparatus, product, or process disclosed, or represents that its use would not infringe privately owned rights. Reference herein to any specific commercial product, process, or service by trade name, trademark, manufacturer, or otherwise does not necessarily constitute or imply its endorsement, recommendation, or favoring by the United States Government or any agency thereof. The views and opinions of authors expressed herein do not necessarily state or reflect those of the United States Government or any agency thereof. 